\title{
The Floodplain Forests of the Mamberamo Basin, Papua, Indonesia (Western New Guinea): Vegetation, Soils, and Local Use
}

\author{
Douglas Sheil 1,2,*(D), Manuel Boissière ${ }^{2,3}$, Miriam van Heist ${ }^{4}$, Ismail Rachman ${ }^{5}$, Imam Basuki ${ }^{2,6}$, Meilinda Wan ${ }^{7}$ \\ and Yoseph Watopa ${ }^{8}$ \\ check for \\ updates \\ 1 Forest Ecology and Forest Management Group, Wageningen University \& Research, \\ P.O. Box 47, 6700 AA Wageningen, The Netherlands \\ 2 Center for International Forestry Research (CIFOR), Bogor 16115, Indonesia; manuel.boissiere@cirad.fr (M.B.); \\ imambasuki1974@gmail.com (I.B.) \\ 3 French Agricultural Research Centre for International Development (CIRAD), Forests and Societies Research \\ Unit, University of Montpellier, Avenue Agropolis, CEDEX 5, 34398 Montpellier, France \\ 4 Soil Geography and Landscape Group, Wageningen University \& Research, \\ P.O. Box 47, 6700 AA Wageningen, The Netherlands; miriam.vanheist@wur.nl \\ 5 Bidang Botani, Indonesian Institute of Sciences (LIPI), Bogor 16911, Indonesia; \\ ismailrachman220459@gmail.com \\ 6 Yayasan Wineco Indonesia Lestari-Winrock International, Menara Mandiri Tower 2, 17th Floor, \\ Jl. Jend. Su-dirman, Kav. 54-55, Jakarta Selatan, DKI Jakarta 12190, Indonesia \\ 7 Grejsdalsvej 218C, 7100 Vejle, Denmark; Heldigdame@gmail.com \\ 8 Lembaga Yayasan Intsia di Tanah Papua, Wahno, Abepura, Jayapura City 99224, Indonesia; \\ watopaocep@gmail.com \\ * Correspondence: douglas.sheil@wur.nl
}

Citation: Sheil, D.; Boissière, M.; van Heist, M.; Rachman, I.; Basuki, I.; Wan, M.; Watopa, Y. The Floodplain Forests of the Mamberamo Basin, Papua, Indonesia (Western New Guinea): Vegetation, Soils, and Local Use. Forests 2021, 12, 1790. https:// doi.org/10.3390/f12121790

Academic Editors: Joseph Hawes and Torbjørn Haugaasen

Received: 21 September 2021 Accepted: 10 December 2021 Published: 16 December 2021

Publisher's Note: MDPI stays neutral with regard to jurisdictional claims in published maps and institutional affiliations.

Copyright: (c) 2021 by the authors. Licensee MDPI, Basel, Switzerland. This article is an open access article distributed under the terms and conditions of the Creative Commons Attribution (CC BY) license (https:/ / creativecommons.org/licenses/by/ $4.0 /)$.
Abstract: New Guinea is the world's largest, most speciose, and most culturally rich tropical island, and the little-studied Mamberamo Basin of Papua (Indonesian New Guinea) is recognised among the region's most-important areas for biological diversity. Here, we examined the floodplain forests in the indigenous territory of Papasena, within the Mamberamo-Foja Wildlife Reserve in the Mamberamo Basin. As part of a training activity with local researchers, students, and civil servants, and with the permission and assistance of the local people, we employed various methods including the field surveys detailed here. We used variable-area tree plots, transects for non-trees and soil sampling, and local informants to document 17 plots: four in old-growth dryland forest, five in old-growth swamp forests (two seasonally flooded and three permanently wet including one dominated by sago, Metroxylon sagu Rottb.), five in secondary forest (fallows), and three in gardens (two in swamps and one on dryland). In total, we measured 475 trees over $10 \mathrm{~cm}$ in diameter at $1.3 \mathrm{~m}(\mathrm{dbh})$. The swamp forests had high local basal areas (highest value $45.1 \mathrm{~m}^{2} \mathrm{ha}^{-1}$ ) but relatively low statures (20 $\mathrm{m}$ but with emergent trees over $40 \mathrm{~m}$ ). In total, 422 morphospecies from 247 genera and 89 different families were distinguished. These included 138 tree species and 284 non-tree plant species. A quarter (105) of the morphospecies lacked species-level identifications. The woody families Rubiaceae, Araceae, Moraceae, and Euphorbiaceae were especially diverse, with 20 or more morphospecies each. Tree richness was highest in dryland forest (plot 7 having 28 species in 40 stems over $10 \mathrm{~cm} \mathrm{dbh}$ ) with more variation in the flooded forests. Non-tree vegetation showed similar patterns ranging from 65 species in one 40-by-5 m primary forest plot to just 5 in one seasonally flooded forest plot. The local people identified many plants as useful. Among trees, at least 59 species were useful for construction (the most common use), while, for non-trees, medicinal uses were most frequent. Inceptisols dominated (12 plots), followed by Ultisols and Entisols (3 and 2 plots, respectively). Drainage appeared poor and nutrient availability low, while land-suitability criteria implied little potential for crops aside from sago. We discuss the implication of local practises and more recent developments that may threaten the conservation of these floodplain systems. We underline the key role of local people in the oversight and protection of these ecosystems.

Keywords: ethnobotany; geomorphology; hydrology; Irian Jaya; Sahul; wetland 


\section{Introduction}

The island of New Guinea comprises the nation of Papua New Guinea in the East and the Indonesian territory of Western New Guinea (henceforth "Papua") in the West. It remains among the most biologically remarkable and least-studied regions of the planet: covering just $0.53 \%$ of the Earth's land $\left(785,753 \mathrm{~km}^{2}\right)$, it is the world's largest, most speciose, and culturally rich tropical island [1-5]. It sustains more wilderness-near-intact natural ecosystems-than anywhere in the Asia-Pacific $[1,5,6]$. One recent island-wide compilation counted 13,634 known plant species of which more than two thirds (68\%) were judged regional endemics [1]. Nonetheless, the biota remains "astoundingly little-known" [7] being relatively unstudied in comparison to other tropical regions $[2,6,8]$. One assessment in the foothills of the Foja Mountains distinguished 487 plant morphospecies (assumed species) and found that $156(32 \%)$ of them could not be matched to known taxa, suggesting a high proportion of undescribed species [9]. The region's diversity results from its dynamic geological history leading to a diversity of habitats [10-13]. For much of the Cenozoic, the wider region supported islands of varying origin, though most modern lands are less than five million years old, while the biota has been influenced by varying sea-levels that provided intermittent terrestrial connections to Australia and among islands $[11,14,15]$. While the ecosystems of Papua remain less impacted by changes in land-cover than nearby regions, this is changing, with road, infrastructure, and land-development initiatives expanding across the territory [6].

Within a poorly described region, Papua's extensive wetlands and floodplain forests are particularly neglected [16]. Recent analyses have highlighted the vast reserves of carbon stored in many of Indonesia's wetland forests, but data from Papua remain sparse [17]. The most-extensive areas of lowland swamp forest in Papua are said to occur along the south coast and in the Mamberamo Basin, but we have not found previous descriptions of such forests and related formations from Mamberamo [16].

The Mamberamo Basin has been judged by regional conservation experts as "Papua's most-important terrestrial biodiversity resource" [8] and is among the world's largest tropical wildernesses [18]. Despite hosting the $1767.5 \mathrm{~km}^{2}$ Mamberamo-Foja Wildlife Reserve, this area is threatened by developments. Major hydropower projects that would flood the basin have been proposed: for example, in the late 1990s, a proposed dam provoked international protests [19], and, while abandoned at the time, such proposals have recurred since (authors pers. obs.). Meanwhile timber concessions have been granted and opened, and new roads now access parts of the basin (authors pers. obs.).

Our surveys were part of a preliminary assessment of the needs, preferences, and concerns of local communities to inform conservation planning [20-23]. Despite the appreciation that conservation needs to include the views of local people, effective methods to achieve this remain a subject of research [6,24-28]. In this context, we applied a set of methods to establish a shared understanding with local communities and assess their needs, concerns, and preferences in conjunction with conventional surveys of vegetation and soils. Here we focus on the results from the biophysical field activities.

Our surveys were performed in 2004, and we underline that many regional processes have been informed by shared principles both before and since. For example, while Indonesia's government has claimed control over forest land in the past, a bottom-up approach that recognises traditional tenure appears more consistent with the nation's constitution [29-31], and, despite past ambiguity, Indonesia's Constitutional Court ruled in 2013 that customary forest lands cannot also be state forests, making many past claims by the government invalid [32]. The government has been forced to find ways to return forest to local communities [31], though the subsequent process has been slow [33]. In Papua, provincial governments have long emphasised the need for alternative development strategies to those pursued elsewhere in Indonesia [34-36]. While this is partly an acknowledgement of the particular development need and challenges in which local Papuans have often benefitted less than other communities [37], it is also a recognition that many past initiatives failed to effectively engage with local culture [38]. Recognition of 
these special needs was formalised when, in 2018, the Governors of the provinces of Papua and West Papua signed the "Manokwari Declaration", a formal statement that commits them to conserve at least $70 \%$ of the region and to ensure infrastructure developments are "environmentally appropriate" and based on principles of sustainable development while also protecting the rights and roles of indigenous people [39]. The declaration also emphasises a commitment to consultative and information-based conservation planning and management [39].

Our study focused on Papasena on the Taritatu River, close to its confluence with the Tariku, all within the Mamberamo-Foja Wildlife Reserve (see Figure 1). The study was undertaken as a student training exercise, guided by researchers from the Indonesian Institute of Sciences (Indonesian "Lembaga Ilmu Pengetahuan Indonesia", or "LIPI") and the Center for International Forest Research (CIFOR) with participation of staff from two local universities, Universitas Negeri Papua and Universitas Cenderawasih and civil servants from the Provincial Environmental Impact Monitoring Agency and those of the Provincial Nature Resource Agency. The Papasena study was performed in parallel with a similar survey in Kwerba, a neighbouring territory on raised terrain $[9,26,40]$. Aside from the training, these studies provided summary data on the nature of the vegetation, soils, and community preferences, and they developed some shared understanding with local people concerning their views of the landscape and its possible protection. Most importantly, the studies provided a basis for additional work in the Foja Mountains [24,41-43] and for advancing conservation and informed land-use planning and related activities with the guidance and consent of the local people [22,27,40,44-46]. Our sampling in Papasena was focused on the level land and floodplains near the main settlement and include various riverside formations (Figure 2), seasonally flooded forests (Figure 3), and vegetation modified by cultivation and other human activities (Figure 4). All these methods involve working closely with local people, and their guidance and explanations informed not only our ethnobotanical results but our choices of where to sample, and our descriptions and interpretations.

At the time of our study, we lacked formal knowledge of what plants and animals the Mamberamo-Foja Wildlife Reserve actually contained. It was also striking how official conservation authorities lacked knowledge of the area, and local people were unaware of the Reserve's rules or boundaries. Our goal in this article is to share our characterisation of the vegetation, soils, and local use and to provide context on the challenges and opportunities for conservation in this region. We also relate our results on the land and vegetation to our findings on the people's relationship with their environment and review recent developments and potential implications for the future. This study is, as far as we know, the first quantitative description of floodplain forests in Mamberamo. 


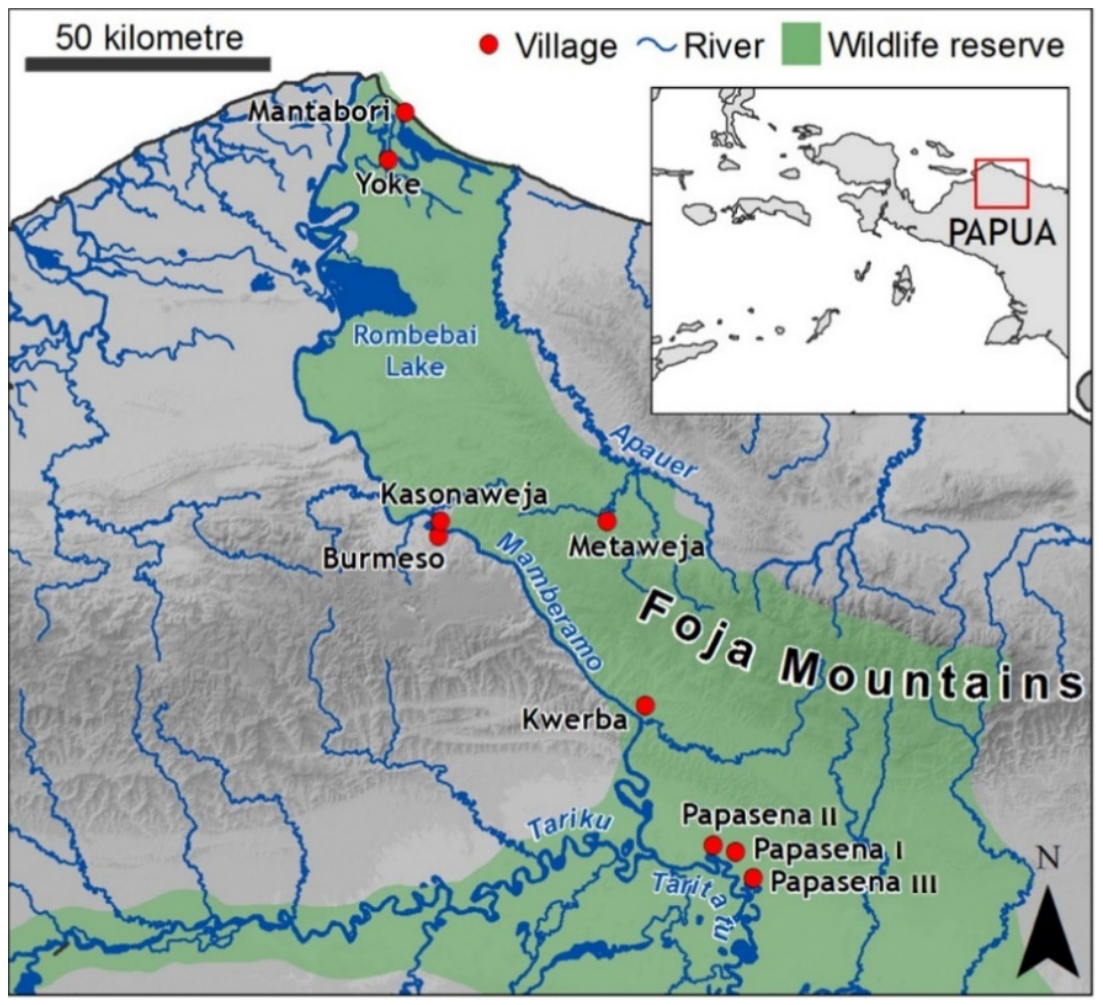

Figure 1. Location of the three settlements comprising Papasena and other notable settlements in the Mamberamo region, Papua, Indonesia. The main settlement, Papasena I, is located at UTM Zone 54M: E 231800 S 9677300. The green area denotes the area within the Mamberamo-Foja Wildlife Reserve. Map modified from that prepared by CIFOR's Mohammad Agus Salim in Ref. [40].

a)

b)
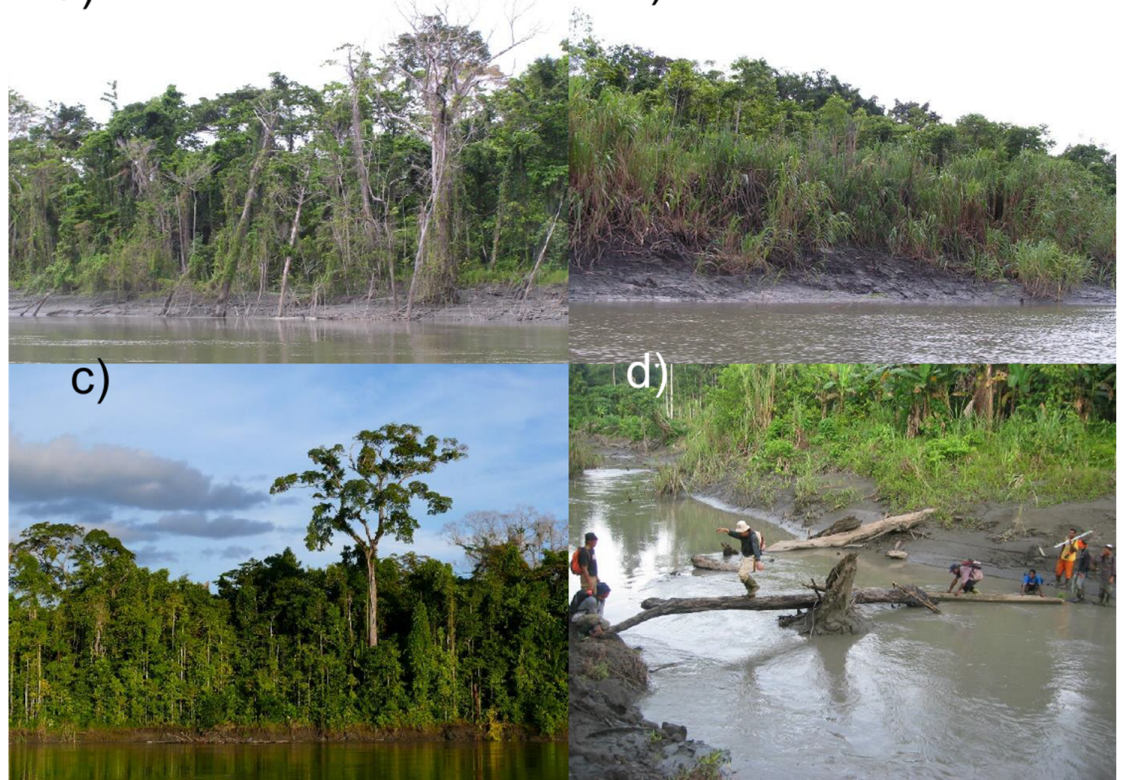

Figure 2. Riverside forests within the Mamberamo Basin are greatly impacted by the dynamic meandering that continually modifies the landscape, with some banks being rapidly eroded (a), while others grow as they accrue new sediments (b). Nonetheless, there are areas where the water flows more gently, and forest edges appear more stable (c). Within the landscape, there are many minor channels that drain the wider landscape and vary considerably in depth, depending on recent rainfall, and are often choked by fallen trees (d). Credits: DS, DS, MB, and MB. 


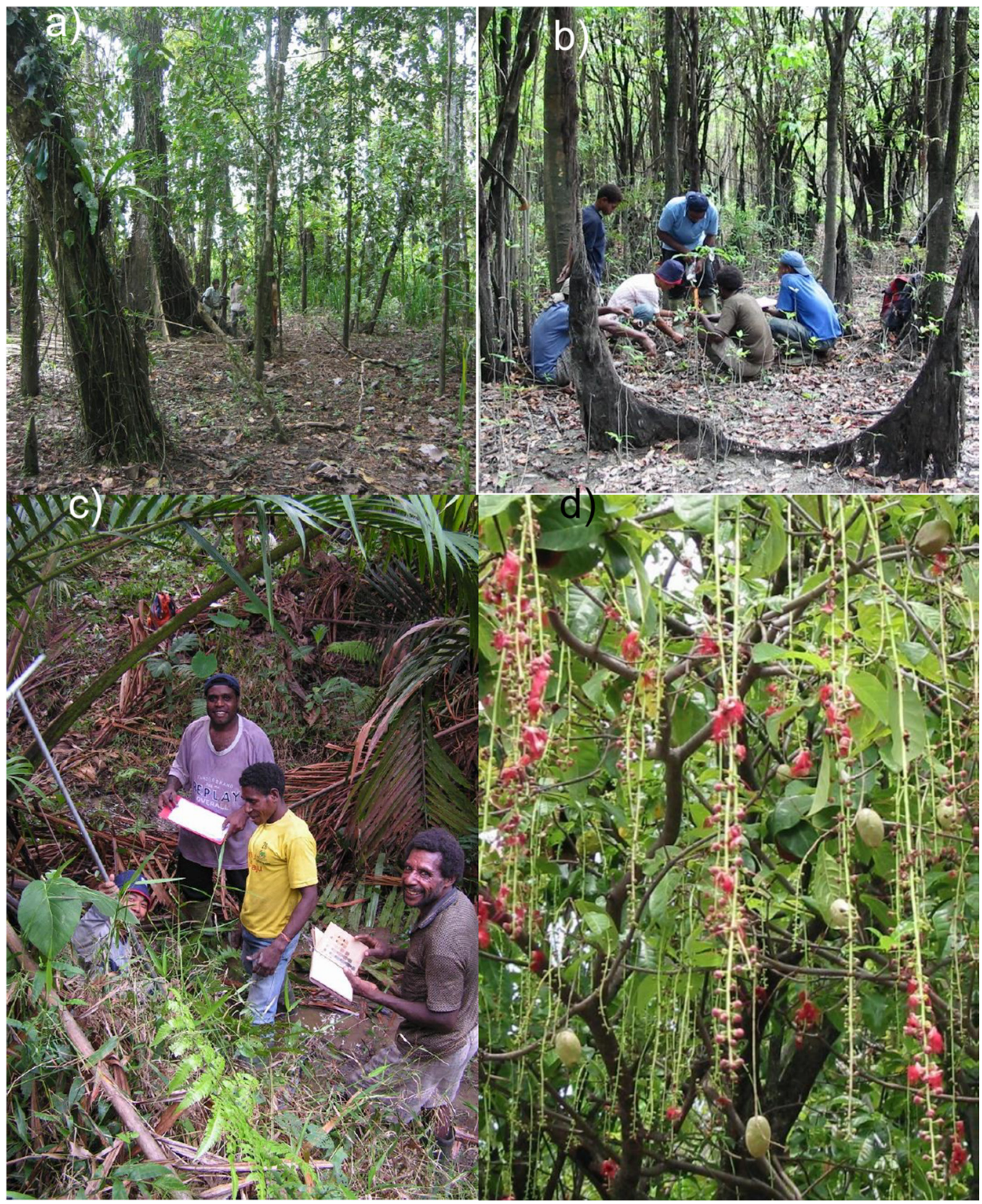

Figure 3. Floodplain forests in the Mamberamo Basin include swamp forests (a), seasonally flooded lakeside forests (b), and sago forests (c) and included distinctive trees such as these flowering Barringtonia sp. (d). Credits: $\mathrm{MB}, \mathrm{MvH}, \mathrm{DS}$, and $\mathrm{MvH}$. 


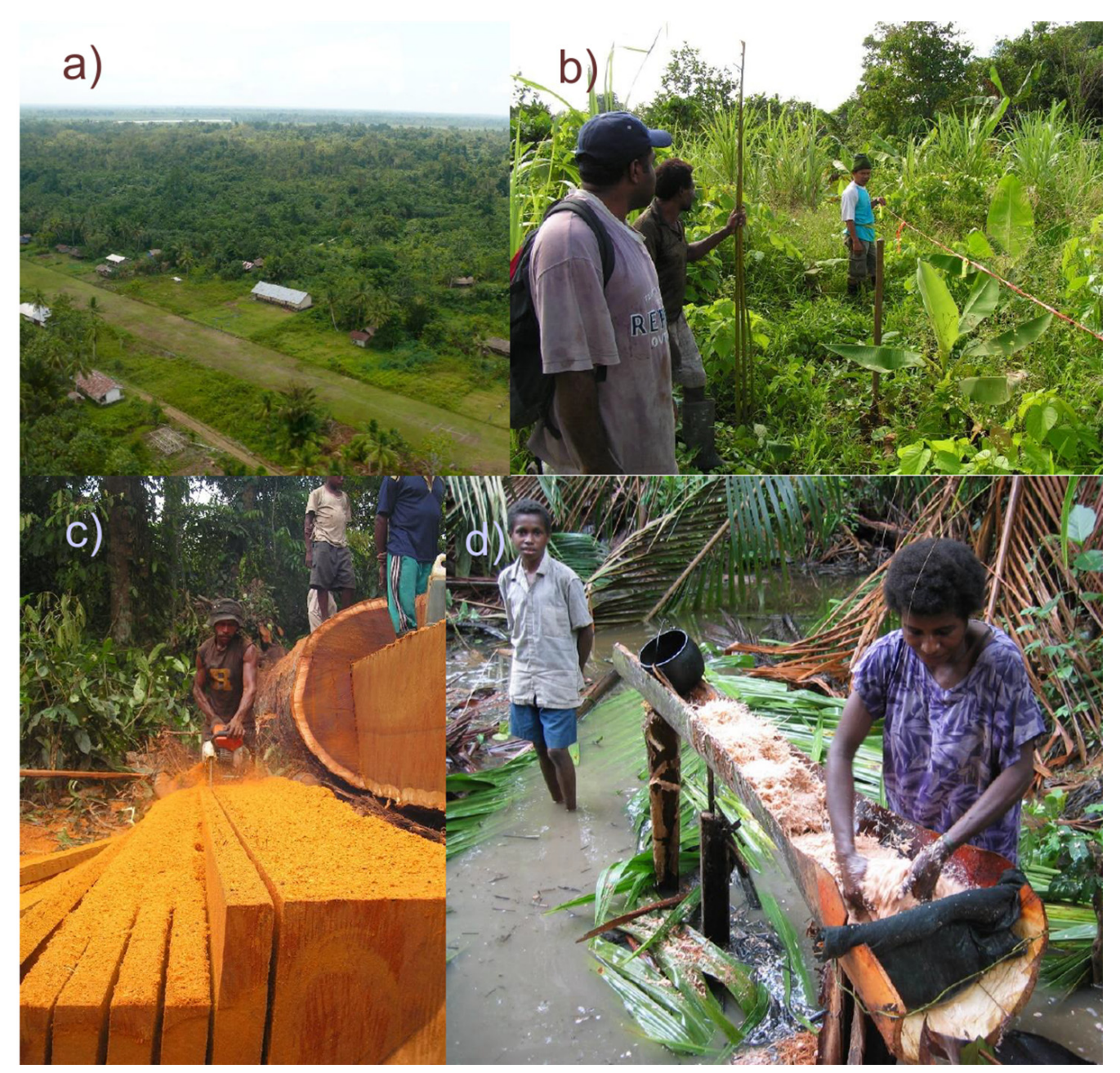

Figure 4. Impacts of human activities are visible around Papasena and its nearby territory as exemplified by an aerial view of the main settlement (a), sampling in a newly opened mixed garden (b), timber cutting (c), and sago processing within the sago swamp forest (d). Credits: MB, DS, DS, and MB.

\section{Materials and Methods}

\subsection{Location, People, and Conservation Context}

Information on the natural history and people of the Mamberamo region is scarce in the scientific literature. The botanists Lam and Kremer each made some riverside collections in the 1920s, and subsequently a couple of scientific expeditions visited the wider region, but none of these explored Papasena or examined floodplain forests. The general description we provide here is a combination of our own observations and other sources [22,25-27,40,45,47].

The Mamberamo Basin-"Meervlakte" in some older texts-is a watershed of $78,000 \mathrm{~km}^{2}$ that drains through the Mamberamo River, which flows northwards via a series of seasonally navigable rapids and narrow gorges that cut through the coastal Van Rees and Foja Mountains before crossing the coastal plains into Cenderawasih Bay. This river is the longest in Papua, and Indonesia's greatest river by mean discharge, estimated at $4500 \mathrm{~m}^{3} \mathrm{~s}^{-1}$, and it remains the world's second-largest unmodified river [48]. The region is geologically young (middle to late Miocene, i.e., less than 15 million years old) and remains tectonically active with frequent earthquakes and landslides in steeper regions. The mountain fringed basin called "Mamberamo" mostly consists of raised floodplains with extensive swamps, forested wetlands, meandering rivers, and oxbow lakes (see Figure 1). The main tributaries are the Taritatu (previously "Idenburg") from the East and 
the Tariku (previously "Rouffaer") from the West. The Taritatu, which flows close to our field study area, rises in poorly mapped country north of Puncak Mandala (4700 m), in an area of fractured karst topography before meandering across the floodplains. The climate is moist tropical with mean daily temperatures at $70 \mathrm{~m}$ above sea level around $26{ }^{\circ} \mathrm{C}$, and an estimated annual rainfall of around $3000 \mathrm{~mm}$. Data from 77 stations across the basin (1950-1990) reveal only minor seasonal variation, with the wettest month being March with just over $300 \mathrm{~mm}$ and the driest being October still with over $220 \mathrm{~mm}$ [46,49].

Human densities are low. According to Indonesian Public Statistics, in 1995, Mamberamo supported an estimated 7000 people (less than one per $10 \mathrm{~km}^{2}$ ). Despite increasing developments across the region, following a decentralisation program and the presence of active logging concessions, natural forests and wetlands dominate. Most people live from subsistence activities: hunting, fishing, and small-scale agriculture. Their diet is primarily focused on sago (Metroxylon sagu Rottb.) and fish. Hunting and gathering play an important role and add variety to the diet. Local communities still depend strongly on their land and the surrounding natural resource base, and traded items include crocodile skins, dried fish-swim-bladders, and gaharu (in English also known as "eaglewood" or "agarwood" - the resinous infected wood from trees in the genera Aquilaria and Gyrinops). Sago palm appears to be natural in the floodplains but is also extensively planted on higher ground near settlements [50,51].

The territory of Papasena supports a cluster of settlements in the floodplains that surround the Daude River where it enters the Taritatu, south of the Foja Mountains in a landscape of floodplains with forest, rivers, and lakes, with the villages and gardens located on slightly raised ground (70 $\mathrm{m}$ above sea level). This area, including the settlement, lies within the Mamberamo-Foja Wildlife Reserve. There are no roads. We focused on Papasena I, which at the time of our study (2004) comprised 377 persons divided over 80 dwellings (related families sometimes share dwellings) and a grass airstrip that can be used when weather permits. During the wet-season floods, Papasena I can be reached by motorized boat. The nearest town, Kasonaweja, is a day-trip away.

No hard rock or stones occur in the vicinity of the settlement. Our auguring and exposures along local riverbanks indicate soft sandstone and siltstone as the primary local bedrock. Some villagers had hard rocks, which they used during cooking in their earth ovens (bakar batu in Indonesian) but told us these had been carried back from the Foja Mountains. People described occurrences of coal, limestone, and warm springs with salty water in more distant locations. Local rivers are turbid with silt, especially after heavy rain. Natural disturbance is a major element of these riverine landscapes (Figure 2a,b,d). While some areas beside slow rivers or lakes may be relatively stable (Figure 2c), the meandering channels of most of the region's larger rivers appear to have been constantly shifting, with some areas destroyed and new sediments accumulating as observed in floodplains elsewhere [52]. These dynamics remain uncharacterized in our region.

Local history provides context for understanding traditional claims, preferences, and knowledge. Papasena's people have various origins, with their own identity, languages, and associated histories. The total territory claimed by people in the settlements was around $1700 \mathrm{~km}^{2}$ (based on joint mapping exercises), but this comprises various subterritories. For example, the Kawena came from the Foja Mountains and settled in the swampy area near the Mamberamo River, to escape conflict with the Ures people to the north. The Khu clan came from the Ari River, and the Khu have been present longer in the location of the current settlement. Extensive contacts with outsiders, and subsequent resettlement and combining of groups, began when a Protestant mission was established in 1961, and the airstrip was built leading people to move together.

Not all external contacts have been benign. During the 1970s, "businessmen" came to hunt crocodiles and trade their skins. This diminished the crocodile population, and the local community considers they were cheated. Following political conflict in 1982, many local people had ended up as refugees in Papua New Guinea, remaining there for over a decade until an international agreement facilitated their return. More recently, competing 
evangelical efforts, coupled to internal disputes, caused the community to divide into three separate settlements (Papasena I remained the most populous).

Tenure does not only apply to land but also to rivers and to wildlife. Each part of the territory is "owned" by a group, or "suku" (the Indonesian term for "ethnic group"), and all commercial activities (trading) must be agreed by the landowner, but subsistence activities (gardening, fishing, or hunting for food) are allowed for everyone from the community, anywhere without restriction. Crocodile hunting remains a major cause of conflicts along this part of the Mamberamo River, with each of the three Papasena settlements claiming exclusive rights, Papasena-I because of its traditional land rights and Papasena II and III because of their proximity to the main river. Crocodile skins remain the most-valued trade items (two species: freshwater and saltwater, Crocodylus novaeguineae and C. porosus, respectively), and the local community view fish (particularly one called ikan sembilang, Family Ariidae), sago, and fruit from the tree matoa (Pometia sp.) as important too. Unlike other communities in the wider region, the people of Papasena showed little interest in trading bird-of-paradise feathers, resins, or fragrant woods.

Papasena's territory lies within the Mamberamo-Foja Wildlife Reserve (Indonesian "Suaka Margasatwa") created in 1982. This designation was intended to protect representative ecosystems of Papua's distinct northern lowlands, the Foja Mountain flora and fauna, and the endemic crocodile, C. novaeguineae. In 1999, as part of a broader decision of the Ministry of Forestry, an extension was added. Reserve boundaries are neither demarcated on the ground nor recognised by local people who were not consulted in the planning process [27,40]. Recognised conservation values in this area are, aside from the crocodiles, mainly associated with the mountains. The globally threatened Scott's tree kangaroo (Dendrolagus scottae) is thought to occur in the Foja Mountains, while important populations of Northern cassowary (Casuarius unappendiculatus), Victoria crowned pigeon (Goura victoria), and Black-spotted cuscus (Spilocuscus rufoniger) are also recognised. Local endemics include Brass's friarbird (Philemon brassi), Golden-fronted bowerbird (Amblyornis flavifrons), Salvadori's fig-parrot (Psittaculirostris salvadorii), and a number of frogs, invertebrate, and plant species [8,53]. More recent expeditions, with the permissions from Papasena and Kwerba that followed our studies, revealed additional animal taxa of conservation interest, and subsequent reports have claimed more than 70 new species $[41,42,54]$. Notable vertebrates (based on personal communications with the researchers involved, and recorded in various widely shared media sources, e.g., $[28,43,54-56])$ included the rediscovery of the endemic Berlepsch's six-wired bird-ofparadise Parotia berlepschi (known previously only from museum material of uncertain origin), as well as multiple new species including a honeyeater (Melipotes carolae), an imperial pigeon (Ducula sp.), a pygmy possum (Cercartetus sp.), a giant rat (Mallomys sp.), a forest wallaby (Dorcopsulus sp.) and a bow-fingered gecko (Cyrtodactylus sp.).

\subsection{Data Collection and Analyses}

Our approach here, developed with communities in Kalimantan (Indonesian Borneo), is part of a broader set of methods that aim to initiate an assessment of biodiversity and its importance to local people [21,57-61]. The methods used include group meetings, exercises, and interviews, as well as a field survey with local informants. An explanation of how these methods were first developed and applied, together with diagrams and examples, is available online in multiple languages, including English and Indonesian [20]. Here, we focus on our field surveys in Mamberamo, which followed a previous period of explanations, training, and practice near Jayapura, the provincial capital, to ensure all participants had practiced the methods and were able to coordinate together to gather the required information and samples.

The study was performed in 2004 and adhered to all regulations and good practice in operation at that time. In that period, permission to access this region was challenging to obtain, especially when there were foreigners involved, but all necessary national and regional permissions were provided and the necessary "travelling letters" (Indonesian 
"surat jalan") granted. Our team included members from several government institutions who ensured all collections were handled following national rules and standards. Our methods adhered to good practice for ethnobiological studies too [62], with effort invested in engaging with the local people, explaining and gaining permission and investing in cooperation at each step. These methods have been used as examples to guide and illustrate good practice-see, for example ref. [20,63].

Introduction and engagement: Through a series of initial visits and discussions, we gained prior permission from the community for the full research team to come and stay for a period of around one month. The full team included a village-focused team, who focused on local views, values, and aspirations, and a field-focused team who gathered the data we consider here. The field team comprised 7-10 people: a soil specialist, a botanist, an ethnobotanist, and a supervisor, who is also the main data recorder, as well as 1-2 assistants and 2-4 local informants selected by the community (at least one man and one woman). On arrival, we initiated a further series of meetings with community members to introduce ourselves and clarify the survey objectives. We used participatory mapping of land types and resources on a base map of major rivers to build a shared understanding of the landscape and learn the main local terms for different land types. Representative sites, guided by the local people, were then selected for field evaluation through our plot-focused set of methods. To locate these sites, we generally discussed plans the day before and agreed to representative locations that could be reached in sufficient time to permit one or more plots to be completed. As our sample sites were within the traditional territory of the "Khu," our main informants were selected from among this clan, and local names were recorded in their language. We allocated most sampling efforts within old-growth "primary" forest, but we also sought comparison with secondary forests (fallows) and cultivated land. Local names guided us in classifying forest types. For example, the two "lakeside forests" (plots 11 and 12) were not called "swamp forests" but were said to flood up to $2 \mathrm{~m}$ during the wet season. We included three cultivated sites: two planted sago gardens (both on waterlogged locations) and one mixed crop garden (on dryland). One plot (13) was made in secondary forest (fallow) near the settlement to demonstrate what we did in the field.

Plot establishment: Having arrived at the general location to be sampled, a point and a direction were arbitrarily chosen (avoiding paths), and, to reduce local biases, a random list of numbers would determine the exact starting point (meters left or right) and direction (degrees from the pre-chosen line) of a $40 \mathrm{~m}$ transect line, which determined all the biophysical measures. For each plot, a standard description of the terrain included GPS readings, accessibility, slope position, steepness and aspect, altitude, surrounding land types, and nearest water features as well as notes on local history and significance, including names for the type and nature of the vegetation and soils.

Vegetation: Tree sampling involved a variable-area approach, with eight short variablelength $10 \mathrm{~m}$ wide transects, four each on each side of the $40 \mathrm{~m}$ baseline [64]. Along each transect, we identified and measured the diameter at $1.3 \mathrm{~m}$ "breast" height (dbh) of the five nearest trees $\geq 10 \mathrm{~cm}$ dbh and the length of the transect, permitting calculations of tree density and basal area. A decision-tree approach was followed for each $10 \mathrm{~m}$ wide variable length transect: (1) If a horizontal distance of $15 \mathrm{~m}$ is travelled without encountering any trees, that cell is recorded as empty (a zero); (2) if at least one tree is tallied before reaching $15 \mathrm{~m}$, and five trees are tallied before reaching $20 \mathrm{~m}$, the cell is recorded as containing five trees and its length is recorded as the distance from the centre-line to the stem centre of the fifth tree; (3) if the plot extends $20 \mathrm{~m}$ before five trees are tallied, sampling stops, and the transect is recorded as containing the number of trees tallied so far, and its length is recorded as $20 \mathrm{~m}$. These counts and distances are based on practical choices, coupled with the requirements for sufficient stems in vegetations analyses with variable stem densities (here the maximum was 40 stems). Plot stem densities and the basal area were calculated as the arithmetic means for the eight variable transects. In low-density tree cover more than half the transects are "empty," density and basal area values are not reliable (stem 
densities are below $20 \mathrm{ha}^{-1}$ ). Nonetheless, this method is versatile and yields approximately equivalent quantities of data per plot in heterogeneous conditions that include both open areas with scattered tree cover and thick areas of dense regrowth [64-66].

A 40-by-5 m transect subdivided into ten (4-by-5 m) subunits was used to evaluate the "non-tree" component of the vegetation: all herbs, ferns, climbers (over $1.5 \mathrm{~m}$ long), epiphytes below $2 \mathrm{~m}$ above the ground, all monocots, and any other non-woody plants with more than cotyledons evident were recorded in each of the 10 subunits. Local informants provided local names, uses, and values that were summarised by standard categories (Table 1). Recognising that we were in a poorly known region, we also made opportunistic botanical observations and collections. This information has been added to provide a more-complete account (for example, regarding the colonising vegetation on the inside edge of river meanders).

Table 1. Categories and explanations used to summarise plant uses and values.

\begin{tabular}{cr}
\hline Category & Explanation \\
\hline Food & Primary and secondary foods; famine foods \\
\hline Medicine & Medicinal and health-related \\
\hline Light construction & Poles and cut timbers for huts, forest camp structures, fences, and other temporary structures \\
\hline Heavy construction & Poles and cut timber for houses and other constructions built to last several years \\
\hline Boat construction & Timber for boats (not including oars or punting poles) \\
\hline Tools & Plant parts used for tools in agriculture, boating or processing; include oars, punting poles, rice \\
pounders, and tool handles
\end{tabular}

For all plant species where taxonomy was uncertain, a numbered herbarium collection (including fertile material when possible) was made for verification and identification in the Bogor Herbarium (now under the Indonesian name "Kebun Raya Bogor" herbarium code $\mathrm{KRB}$ ). When there were multiple examples of the same apparent species, based on form and indicative characters, we grouped these into "morphospecies" and cross-referenced data and labels accordingly. We later revised and standardized our names, when available, following the online International Plant Names Index http:/ / www.ipni.org (last accessed on 15 November 2021). Those taxa that could not be identified remained as morphospecies.

In addition, the furcation index of each tree was recorded (" $F$-index": a measure of overall percentage height, where apical dominance is absent and usually considered as a simple measure of past disturbance, with higher values typically resulting from broken stems and coppicing, and low values indicating high apical dominance-palms and pandanus are excluded in plot summaries) [67]. Local informants provided the local names and use(s) for each tree. Tree-species richness was summarized using a simple "Rarefaction richness index" (=log (number of species)/ $\log$ (number of stems); a measure recommended for small samples) to ease comparison among plots [68]. 
Soil and cropland suitability: In the middle of each transect, a $60 \mathrm{~cm}$-deep soil profile was excavated and described (depth, colour, texture, structure, consistency, and $\mathrm{pH}$, as well as moisture regime, matrix node, pores, and roots) [69]. Additional soil collections were taken by augur at $10 \mathrm{~m}$ and $30 \mathrm{~m}$ along the transect, with composite samples made from depths of $0-20 \mathrm{~cm}$ and 21-40 cm [58]. Subsequent analyses included measures of physical properties: texture and bulk density and chemical properties: $\mathrm{pH}$ in a soil suspension with distilled water for " $\mathrm{pH}_{\mathrm{H} 20}$," and also a $1 \mathrm{M}$ potassium chloride $(\mathrm{KCl})$ solution for " $\mathrm{pH}_{\mathrm{KCl}}$," C (organic carbon), $\mathrm{N}$ (total nitrogen Kjeldahl procedure), $\mathrm{P}_{2} \mathrm{O}_{5}$ (available phosphorus), $\mathrm{K}_{2} \mathrm{O}$ (available potassium), $\mathrm{Ca}^{2+}$ (calcium), $\mathrm{Mg}^{2+}$ (magnesium), $\mathrm{Na}^{+}$ (sodium), $\mathrm{K}^{+}$(exchangeable potassium), cation exchange capacity (CEC), base saturation, $\mathrm{Fe}^{3+}$ (iron), and $\mathrm{Al}^{3+}$ (aluminium, $\mathrm{NH}_{4} \mathrm{OAc}$ procedure [70]) were assessed. These measures allowed us to apply the standard assessments used in Indonesia to judge land suitability for sustained fertilizer-free production across a range of crops with recognised requirements for specific soil nutrients, drainage, and other properties [71].

\section{Results}

\subsection{Plot Locations and Vegetation}

The local people distinguished seven general categories of vegetation in the landscape surrounding Papasena: primary forest (old-growth dryland forest), swamp forest (natural wetlands dominated by trees), lakeside forest (seasonally flooded forest), sago forest (a form of swamp forest dominated by sago palm), fallow (secondary forest), mixed garden, and sago garden. Two additional types, mountain forest and damar forest (forest types on the hills and mountains to the north above the floodplains) were also reported but were too distant to visit and assess. Our plots in 17 locations (Table 2) included all of the accessible vegetation categories, which were supplemented by additional observations. In total, we recorded 475 trees over $10 \mathrm{~cm}$ dbh (12 were planted).

Table 2. Forest structure by plot for stems $\geq 10 \mathrm{~cm}$ diameter at $1.3 \mathrm{~m}$ height $(\mathrm{dbh})$.

\begin{tabular}{|c|c|c|c|c|c|c|c|c|c|}
\hline Vegetation Type & Plot & Trees & $\begin{array}{l}\text { Mean } \\
\text { Height }\end{array}$ & $\begin{array}{c}\text { Max } \\
\text { Height }\end{array}$ & $\begin{array}{c}\text { Mean } \\
\text { dbh }\end{array}$ & $\begin{array}{l}\text { Max } \\
\text { dbh }\end{array}$ & $\begin{array}{l}\text { Basal } \\
\text { Area }\end{array}$ & $\begin{array}{c}\text { Tree } \\
\text { Density }\end{array}$ & $\begin{array}{l}\text { Mean } \\
\text { F-Index }\end{array}$ \\
\hline & & $N^{*}$ & $\mathrm{~m}$ & $\mathrm{~m}$ & $\mathrm{~cm}$ & $\mathrm{~cm}$ & $\mathrm{~m}^{2} \mathrm{ha}^{-1}$ & $\mathrm{ha}^{-1}$ & $\%$ \\
\hline \multirow[t]{4}{*}{ Primary forest } & 2 & 40 & 21.1 & 50 & 25.3 & 50 & 21.1 & 484 & 14 \\
\hline & 3 & 40 & 20.8 & 45 & 24.6 & 45 & 19.8 & 457 & 13 \\
\hline & 5 & 40 & 22.0 & 62 & 19.2 & 35 & 18.7 & 379 & 10 \\
\hline & 7 & 40 & 21.9 & 65 & 19.9 & 45 & 19.4 & 392 & 11 \\
\hline \multirow{2}{*}{ Swamp forest } & 1 & 39 & 27.7 & 81.5 & 21.2 & 45 & 38.4 & 505 & 31 \\
\hline & 4 & 35 & 34.0 & 72 & 19.2 & 35 & 33.4 & 279 & 47 \\
\hline \multirow[t]{2}{*}{ Lakeside forest } & 11 & 40 & 20.9 & 60 & 7.9 & 14 & 19.3 & 484 & 61 \\
\hline & 12 & 37 & 32.6 & 77 & 14.1 & 32 & 45.1 & 437 & 37 \\
\hline Sago forest & 6 & 31 & 25.5 & 48.5 & 17.7 & 33 & 26.3 & 453 & 14 \\
\hline \multirow{2}{*}{$\begin{array}{c}\text { Secondary: } \\
\text { Young fallow }<5 \text { years }\end{array}$} & 14 & 17 & 17.0 & 33 & 7.6 & 11 & 4.0 & 81 & 34 \\
\hline & 15 & 2 & 13.1 & 17 & 18.8 & 24 & $n a^{* *}$ & $<20$ & 45 \\
\hline \multirow{3}{*}{$\begin{array}{c}\text { Secondary: } \\
\text { Old fallow > } 5 \text { years }\end{array}$} & 10 & 40 & 16.6 & 41.4 & 13.1 & 25 & 20.3 & 794 & 26 \\
\hline & 13 & $13(2)$ & 19.7 & 31 & 9.9 & 16 & 2.8 & 81 & 16 \\
\hline & 16 & 37 & 18.8 & 36.5 & 11.3 & 16 & 17.7 & 555 & 63 \\
\hline \multirow[t]{2}{*}{ Sago garden } & 9 & $10(6)$ & 25.7 & 35 & 7.7 & 12 & 6.7 & 96 & 40 \\
\hline & 17 & $13(4)$ & 39.3 & 60 & 13.5 & 21 & 11.0 & 81 & 15 \\
\hline Mixed garden & 8 & 1 & 40.0 & 40 & 10.0 & 10 & $n a$ & $<20$ & 100 \\
\hline
\end{tabular}

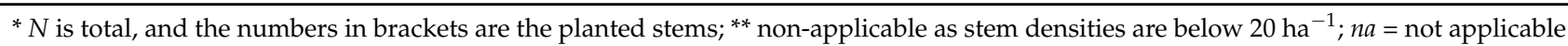
(when counts are insufficient). 


\subsection{Structure}

High basal area was found in the swamp forests and one of the lakeside forests (plot 12), and the highest stem densities occurred in old secondary forest (plot 10) (Table 2). Sago and lakeside forest were of relatively short stature, with dryland forests including emergent individuals such as Intsia bijuga (Colebr.) Kuntze, Teijsmanniodendron bogoriense Koord., and Maniltoa schefferi K. Schum. reaching to around $50 \mathrm{~m}$. Most trees in secondary forests were comparatively short, although some larger trees, likely relics from older forest, also occurred. The mean furcation index was low in the primary and sago forests but higher in lakeside, swamp, and secondary forests (Table 2). While climbers, lianas, and herbs were found in most vegetation types, they were scarce in some swamp and lakeside forest plots (Figure 3a,b).

\subsection{Diversity}

We recorded 138 distinct tree species in our variable area plots, and 284 distinct non-tree morphospecies in our 5-by- $40 \mathrm{~m}$ transects (Table 3). In total, 422 morphospecies were distinguished from 850 voucher specimens, belonging to 247 identified genera in 89 different families. A quarter (105 or $25.5 \%$ ) of these morphospecies remained unidentified to the species level and unmatched to herbarium material: of these, 21 could not be confidently ascribed to a genus, while 14 were unidentified at a family level. The woody families Rubiaceae, Araceae, Moraceae, and Euphorbiaceae were especially diverse, with 20 or more morphospecies each.

Table 3. Stem counts $(N$, trees $\geq 10 \mathrm{~cm}$ diameter at $1.3 \mathrm{~m}$ height $(\mathrm{dbh}))$, species counts $(n)$ by lifeform, and richness by plot.

\begin{tabular}{|c|c|c|c|c|c|c|c|c|c|c|c|c|c|c|c|c|c|}
\hline Plot & 2 & 3 & 5 & 7 & 1 & 4 & 11 & 12 & 6 & 14 & 15 & 10 & 13 & 16 & 9 & 17 & 8 \\
\hline $\begin{array}{l}\text { Vegetation } \\
\text { type }\end{array}$ & $P$ & $P$ & $P$ & $P$ & $S$ & $S$ & $L$ & $L$ & $S F$ & $F$ & $F$ & $F$ & $F$ & $F$ & $S G$ & $S G$ & $M G$ \\
\hline $\begin{array}{c}N \text { total } \\
\text { (planted) }\end{array}$ & 40 & 40 & 40 & 40 & 39 & 35 & 40 & 37 & 31 & 16 & 2 & 40 & $13(2)$ & 37 & $10(6)$ & $13(9)$ & 1 \\
\hline Trees $n$ & 18 & 27 & 25 & 28 & 17 & 12 & 4 & 4 & 14 & 8 & 2 & 13 & 8 & 20 & 5 & 6 & 1 \\
\hline $\begin{array}{l}\text { Richness } \\
\text { index ** }\end{array}$ & 0.784 & 0.893 & 0.873 & 0.903 & 0.773 & 0.699 & 0.376 & 0.384 & 0.769 & 0.750 & 1.000 & 0.695 & 0.811 & 0.830 & 0.699 & 0.699 & $n a$ \\
\hline Non-trees $n$ & 65 & 49 & 61 & 50 & 29 & 28 & 8 & 5 & 24 & 43 & 38 & 46 & 33 & 54 & 27 & 43 & 34 \\
\hline $\begin{array}{c}\text { Climber } \\
\text { (non-woody) }\end{array}$ & 19 & 14 & 24 & 31 & 9 & 12 & 2 & 1 & 12 & 17 & 15 & 24 & 14 & 21 & 8 & 20 & 10 \\
\hline $\begin{array}{c}\text { Liana } \\
\text { (woody climber) }\end{array}$ & 11 & 7 & 9 & 5 & 6 & 4 & 2 & 2 & & 1 & 1 & 1 & & 6 & & 1 & \\
\hline $\begin{array}{c}\text { Palms } \\
\text { (tree palms) }\end{array}$ & 5 & 1 & 3 & & & & & & & & & & & & & & \\
\hline Pandans & 1 & & 1 & 1 & 1 & 1 & & & 1 & & & 2 & & 2 & 1 & & \\
\hline $\begin{array}{l}\text { Epiphytes } \\
\text { (not ferns) }\end{array}$ & & & 2 & 1 & 5 & 2 & & & 1 & & & 1 & & & 1 & & \\
\hline Epiphytic ferns & 3 & 2 & 1 & 2 & 2 & 4 & & & 1 & & & 1 & & & & & \\
\hline Climbing ferns & 3 & 4 & 3 & 1 & 2 & 1 & & & 1 & 1 & 1 & & & 1 & & 1 & \\
\hline $\begin{array}{l}\text { Terrestrial } \\
\text { ferns }\end{array}$ & 7 & 6 & 4 & & 2 & 2 & 1 & 1 & 2 & 7 & 3 & 2 & 4 & 5 & 3 & 6 & 5 \\
\hline Other herbs & 16 & 15 & 14 & 9 & 2 & 2 & 3 & 1 & 6 & 17 & 18 & 15 & 15 & 19 & 14 & 15 & 19 \\
\hline
\end{tabular}

Tree species richness was highest in primary forest (plot 7 having 28 species in 40 stems), although some old fallow plots had similar richness, allowing for stem numbers (Table 3). Overall patterns for our non-tree species were similar, with the highest values found in primary forest and old fallows. Much of this difference appears due to climbers and lianas. Understorey palm species were only found in the primary forest. 


\subsection{Composition}

Common canopy species in the primary forest included Gymnacranthera paniculata Warb., Horsfieldia irya (Gaertn.) Warb., and Pothos versteegii Engl. Tree species with more than one individual per plot included: Gymnacranthera sp.; Santiria laevigata Blume, Teijsmanniodendron sp.; Antidesma sp.; Aporosa Blume; Celtis philipinensis Blanco; and Horsfieldia sp. Common canopy species in the swamp forest were Kleinhovia hospita L., Endospermum moluccanum Becc., and Pandanus sp. The lakeside forests we sampled were said to flood to over one meter for several months each year. These forests lacked understorey and were dominated by Barringtonia racemosa Roxb. and Nauclea orientalis L. Other common trees in these seasonally flooded forests included Neonauclea obversifolia (Valeton) Merr. and L.M.Perry, N. versteeghii Merr. and L.M.Perry, Vitex quinata F.N.Williams, Planchonia papuana R.Knuth, H. irya, Cerbera floribunda K.Schum., Terminalia brassii Exell., and Intsia bijuga and Syzygium sp. Lianas were common in some locations and included Cayratia trifolia Domin, Mucuna novoguineensis Scheff., Dalbergia sp., Cissus repens Lam., Piper sp., Rhaphidophora korthalsii Schott, Pothos versteegii, and Flagellaria indica L. We observed that palms, including rattans, were often abundant in disturbed swamp forest. Common palms included Caryota rumphiana Mart., Licuala sp., M. sagu., Arenga sp., Gulubia costata (Bailey) Becc. and Rhopaloblaste brassii H.E.Moore and the rattans Calamus hollrungii Becc., C. warburgii K.Schum., C. sp., and Korthalsia brassii Burret. Tree species in these disturbed areas included Alseodaphne sp., Phoebe cuneata (Blume) Blume, Campnosperma auriculatum (Blume) Hook.f., Gnetum gnemon L., H. irya, Mastixiodendron pachyclados Melch., Neubergia sp. (perhaps N. tubiflora Blume), Pimelodendron amboinicum Hassk., and Tabernaemontana aurantiaca Gaudich.

Sago forest and sago gardens were dominated by sago palms, M. sagu. In mixed gardens and fallows, we found pioneer trees such as Ficus ribes Reinw. ex Blume and Macaranga mappa Muell. Arg., remnant forest trees like Pothos versteegii and Tabernaemontana sp., and occasional planted fruit trees including various species of Artocarpus. Sago tended to occur with various other tree species, including $N$. versteeghii, $N$. obversifolia, Bischoffia cf. javanica F.Muell., P. papuana, Terminalia brassii, Garcinia latissimi Miq., Intsia bijuga, Horsfieldis irya (Gaertn.) Warb., Tabernaemontana aurantiaca, and E. moluccanum. Common lianas in sago forests and sago gardens included: F. indica., M. novoguinensis, Rhaphidophora korthalsii, Piper sp., Pothos versteegii, Faradaya papuana Scheff, Derris sp.; Freycinetia spp.; Dioscorea sp.; and Cissus repens. Understorey species were sometimes scarce but included Mapania tenuiscapa C.B.Clarke, Mapania sp., Alocasia brancifolia (Schott) A.Hay, Helmintostachys zeylanica (L.) Kaulf., Etlingera sp., Curculigo capitulata (Lour.) Kuntze, and Donax canniformis Rolfe.

Mixed crop gardens were generally located in clusters near habitation, or on the river banks, and were mostly planted with tubers [22,47] such as sweet potato (Ipomoea batatas (L.) Lam.) and cassava (Manihot utilissima Pohl). In these gardens, people also grow banana (Musa spp.); other fruit trees, such as coconut Cocos nucifera L., Artocarpus altilis (Parkinson) Fosberg, A. heterophyllus, chili Capsicum frutescens L., papaya Carica papaya L., star fruit Averrhoa carambola L., water apple Syzygium aqueum (Burm.f.) Alston, and guava Psidium guajava L.; and various vegetables.

The most commonly recorded non-tree taxa across all plots included the climbers Merremia peltata Merr. (Convolvulaceae), Dioscorea nummularia Lam. (Dioscoreaceae), and Rhaphidophora versteegii Engl. and K.Krause (Araceae) found in 12, 11, and 9 plots, respectively. The herb Schismatoglottis calyptrata (Roxb.) Zoll. and Moritzi (Araceae) was recorded in nine plots, and the terrestrial fern Nephrolepis biserrata (Sw.) Schott (Oleandraceae) and the grass Centotheca lappacea Desv. (Poaceae) were each found in seven plots.

We did not complete any plots in the young low vegetation of river meanders, but these areas tend to be colonized by tall grasses Saccharum spontaneum L. with woody plants including Timonius sp., Colona scabra Burret, Nauclea orientalis, Neonauclea obversifolia, N. versteeghii, Artocarpus altilis, Euodia elleryana F.Muell., P. papuana, and Terminalia brassii. Climbers and lianas include M. novoguineensis, C. trifolia, Stephania hernandiifolia Walp., Derris sp., Dalbergia densa Benth., and F. indica. 


\subsection{Valued Plants}

While local people identified useful plants in all plots, more were reported in the more-species-rich plots (Table 4). On average, among all plots, $82 \%$ of trees and around $42 \%$ of non-tree morphospecies had some recognized use or value. For trees, unique species-value combinations were most commonly related to heavy construction (59), while firewood, hunting place, tools, and food were also common $(>10)$. For non-trees, the most-frequent unique species-value combinations were medicinal (13), while food (9), cordage/weave (7), and hunting place (6) were also common.

Table 4. Local uses and values recognized by local informants by category per plot per species, for tree $(T)$ and non-tree $\left(N_{t}\right)$ plants. One species can have more than one value (see Table 1 for definitions).

\begin{tabular}{|c|c|c|c|c|c|c|c|c|c|c|c|c|c|c|c|c|c|c|}
\hline Plot & & 2 & 3 & 5 & 7 & 1 & 4 & 11 & 12 & 6 & 14 & 15 & 10 & 13 & 16 & 9 & 17 & 8 \\
\hline Vegetation type * & & $P$ & $P$ & $P$ & $P$ & $S$ & $S$ & $L$ & $L$ & $S F$ & $F$ & $F$ & $F$ & $F$ & $F$ & $S G$ & $S G$ & $M G$ \\
\hline Use & $T / N_{t}$ & & & & & & & & & & & & & & & & & \\
\hline \multirow[t]{2}{*}{ Boat construction } & $T$ & 0 & 2 & 1 & 2 & 2 & 0 & 0 & 1 & 2 & 2 & 0 & 2 & 0 & 2 & 0 & 1 & 1 \\
\hline & $N_{t}$ & 0 & 0 & 0 & 0 & 0 & 0 & 0 & 0 & 0 & 0 & 0 & 0 & 0 & 0 & 0 & 0 & 0 \\
\hline \multirow[t]{2}{*}{ Cordage/weave } & $T$ & 1 & 0 & 0 & 0 & 0 & 0 & 0 & 0 & 0 & 0 & 0 & 1 & 0 & 0 & 0 & 0 & 0 \\
\hline & $N_{t}$ & 3 & 2 & 2 & 3 & 1 & 3 & 1 & 1 & 1 & 1 & 3 & 4 & 3 & 6 & 3 & 8 & 1 \\
\hline \multirow[t]{2}{*}{ Firewood } & $T$ & 2 & 2 & 20 & 10 & 0 & 7 & 2 & 2 & 7 & 6 & 0 & 4 & 3 & 14 & 2 & 1 & 14 \\
\hline & $N_{t}$ & 0 & 0 & 0 & 0 & 0 & 0 & 0 & 0 & 0 & 0 & 0 & 3 & 0 & 0 & 0 & 0 & 0 \\
\hline \multirow[t]{2}{*}{ Food } & $T$ & 3 & 3 & 5 & 3 & 2 & 3 & 0 & 0 & 2 & 1 & 1 & 0 & 7 & 0 & 2 & 2 & 0 \\
\hline & $N_{t}$ & 1 & 3 & 2 & 1 & 2 & 2 & 2 & 0 & 1 & 7 & 3 & 3 & 7 & 3 & 5 & 3 & 14 \\
\hline \multirow[t]{2}{*}{ Heavy construction } & $T$ & 14 & 19 & 25 & 20 & 11 & 8 & 0 & 1 & 6 & 7 & 1 & 4 & 2 & 14 & 4 & 5 & 0 \\
\hline & $N_{t}$ & 6 & 0 & 2 & 0 & 0 & 0 & 0 & 0 & 0 & 0 & 0 & 2 & 0 & 0 & 0 & 2 & 0 \\
\hline \multirow[t]{2}{*}{ Light construction } & $T$ & 1 & 0 & 0 & 0 & 0 & 0 & 1 & 1 & 0 & 0 & 0 & 2 & 0 & 1 & 0 & 0 & 0 \\
\hline & $N_{t}$ & 0 & 0 & 1 & 0 & 0 & 0 & 0 & 0 & 0 & 0 & 0 & 0 & 0 & 0 & 0 & 0 & 0 \\
\hline \multirow[t]{2}{*}{ Hunting ingredients } & $T$ & 0 & 0 & 0 & 0 & 1 & 0 & 0 & 1 & 0 & 0 & 0 & 0 & 0 & 0 & 0 & 0 & 1 \\
\hline & $N_{t}$ & 1 & 6 & 0 & 1 & 1 & 3 & 1 & 0 & 1 & 0 & 1 & 2 & 0 & 0 & 1 & 0 & 1 \\
\hline \multirow[t]{2}{*}{ Hunting place } & $T$ & 1 & 9 & 19 & 5 & 0 & 1 & 1 & 2 & 0 & 3 & 0 & 6 & 0 & 11 & 1 & 2 & 3 \\
\hline & $N_{t}$ & 5 & 5 & 2 & 2 & 0 & 0 & 4 & 0 & 0 & 3 & 0 & 4 & 2 & 3 & 3 & 4 & 3 \\
\hline \multirow[t]{2}{*}{ Hunting tools } & $T$ & 0 & 1 & 0 & 0 & 0 & 1 & 0 & 0 & 0 & 0 & 0 & 0 & 0 & 0 & 0 & 0 & 0 \\
\hline & $N_{t}$ & 2 & 0 & 0 & 0 & 0 & 0 & 0 & 0 & 0 & 0 & 1 & 0 & 0 & 0 & 0 & 0 & 0 \\
\hline \multirow[t]{2}{*}{ Medicine } & $T$ & 0 & 0 & 1 & 0 & 2 & 0 & 0 & 2 & 0 & 3 & 0 & 1 & 3 & 3 & 0 & 2 & 8 \\
\hline & $N_{t}$ & 4 & 7 & 5 & 6 & 4 & 6 & 1 & 2 & 2 & 3 & 5 & 9 & 8 & 4 & 2 & 7 & 8 \\
\hline \multirow[t]{2}{*}{ Ornamental/ritual } & $T$ & 0 & 0 & 0 & 0 & 0 & 0 & 0 & 0 & 0 & 0 & 0 & 0 & 0 & 0 & 0 & 0 & 0 \\
\hline & $N_{t}$ & 0 & 2 & 0 & 0 & 0 & 0 & 0 & 0 & 0 & 0 & 0 & 0 & 1 & 0 & 0 & 0 & 1 \\
\hline \multirow[t]{2}{*}{ Future } & $T$ & 0 & 0 & 0 & 0 & 0 & 0 & 0 & 0 & 0 & 0 & 0 & 0 & 0 & 0 & 0 & 0 & 0 \\
\hline & $N_{t}$ & 0 & 0 & 1 & 0 & 0 & 0 & 0 & 0 & 0 & 0 & 0 & 0 & 0 & 0 & 0 & 0 & 0 \\
\hline \multirow[t]{2}{*}{ Recreation } & $T$ & 0 & 1 & 1 & 0 & 1 & 2 & 0 & 0 & 0 & 0 & 0 & 0 & 0 & 0 & 1 & 0 & 0 \\
\hline & $N_{t}$ & 3 & 4 & 1 & 1 & 1 & 3 & 0 & 0 & 0 & 4 & 1 & 3 & 1 & 0 & 0 & 5 & 1 \\
\hline \multirow[t]{2}{*}{ Tools } & $T$ & 0 & 2 & 3 & 4 & 2 & 2 & 1 & 1 & 1 & 1 & 1 & 5 & 0 & 12 & 0 & 4 & 1 \\
\hline & $N_{t}$ & 7 & 4 & 1 & 2 & 1 & 2 & 0 & 0 & 1 & 1 & 1 & 5 & 2 & 3 & 2 & 1 & 1 \\
\hline \multirow[t]{2}{*}{ Other } & $T$ & 1 & 0 & 0 & 0 & 0 & 0 & 0 & 0 & 0 & 0 & 0 & 0 & 0 & 0 & 0 & 0 & 1 \\
\hline & $N_{t}$ & 0 & 1 & 2 & 0 & 0 & 0 & 0 & 0 & 1 & 0 & 0 & 0 & 0 & 0 & 0 & 0 & 0 \\
\hline \multirow[t]{2}{*}{ Total uses } & $T$ & 32 & 39 & 75 & 44 & 21 & 24 & 5 & 11 & 18 & 23 & 3 & 25 & 15 & 57 & 10 & 17 & 29 \\
\hline & $N_{t}$ & 23 & 34 & 19 & 16 & 10 & 19 & 9 & 3 & 7 & 19 & 15 & 35 & 24 & 19 & 16 & 30 & 30 \\
\hline Sum & & 55 & 73 & 94 & 60 & 31 & 43 & 14 & 14 & 25 & 42 & 18 & 60 & 39 & 76 & 26 & 47 & 59 \\
\hline
\end{tabular}

*Vegetation types: $P=$ primary forest; $S=$ swamp forest; $L=$ lakeside forest; $S F=$ sago forest; $F=$ fallow (secondary forest); $M G=$ mixed garden; $S G$ = sago garden. 


\subsection{Soil and Land Suitability}

Three soil orders were encountered (Table 5) of which Inceptisols were prevalent (12 plots), followed by Ultisols (3 plots) and Entisols (2). All soils appeared fine textured with poor drainage. Soils generally had a low cation exchange capacity (CEC) and low levels of potassium and phosphorus, while values for the seasonally flooded lakeside plots were marginally higher than other sites (Table 6). A broad range of $\mathrm{pH}$ values was observed, especially among the Inceptisols, ranging from above $\mathrm{pH} 7$ in two of the swamp forests (plots 1 and 4 ) to well below 5 for the sago forest, which also had a high level of $\mathrm{Al}^{3+}$ ions (plot 6). The greatest soil carbon values, by an order of magnitude, were from histic soils (Inceptisols) found in this sago forest (Table 6).

Table 5. Soil properties in the Mamberamo Basin as described by visible characteristics.

\begin{tabular}{ccccc}
\hline SOIL TYPES & Forest Types: Plot Numbers & Depth $\mathbf{( c m )}$ & Colour & Drainage \\
& Primary forest: 7,3 & 80 & Brown, yellow, grey & Quite impeded \\
\cline { 2 - 5 } Inceptisol & Fallow: 10, 13, 14, 16 & 80 & Yellowish brown, grey & Quite impeded \\
\cline { 2 - 5 } & Lakeside forest: 11 & 80 & Brown, grey, black & Quite impeded to impeded \\
\cline { 2 - 5 } & $\begin{array}{c}\text { Swamp forest and sago } \\
\text { forest: } 1,4,6\end{array}$ & 100 & Black, brown, grey & Impeded to very impeded \\
\cline { 2 - 5 } Entisol & Sago garden: 9 & 100 & Dark brown, grey, dark grey & Quite impeded \\
\hline \multirow{2}{*}{ Ultisol } & $\begin{array}{c}\text { Lakeside forest and sago } \\
\text { garden: } 12,17\end{array}$ & 100 & Black, brown, grey & Quite impeded to very impeded \\
\cline { 2 - 5 } & Primary forest: $2,5,15$ & 100 & Brown, yellow, grey & Quite impeded to impeded \\
\hline
\end{tabular}

Table 6. Soil $(0-20 \mathrm{~cm})$ properties in the Mamberamo Basin by selected physical and chemical characteristics and fertility assessment.

\begin{tabular}{|c|c|c|c|c|c|c|c|c|c|c|c|c|c|c|}
\hline $\begin{array}{l}\text { Plot } \\
\text { No. }\end{array}$ & $\begin{array}{c}\text { Veg' } \\
\text { Type* }\end{array}$ & Soil Type & $\underset{\mathrm{pH}_{\mathrm{KCl}}}{\mathrm{pH}_{\mathrm{H}_{2} \mathrm{O}^{-}}}$ & $\begin{array}{c}\text { Sand-Silt-Clay } \\
(\%)\end{array}$ & $\begin{array}{l}\text { Bulk Density } \\
\left(\mathrm{g} \mathrm{cm}^{-3}\right)\end{array}$ & $\begin{array}{c}\mathrm{C} \\
(\%)\end{array}$ & $\begin{array}{c}\text { Total N } \\
(\%)\end{array}$ & $\begin{array}{c}\mathrm{Al}^{3+} \\
(\mathrm{me} / 100 \mathrm{~g})\end{array}$ & $\begin{array}{l}\mathrm{P}_{2} \mathrm{O}_{5} \\
(\mathrm{ppm})\end{array}$ & $\begin{array}{c}\mathrm{K}_{2} \mathrm{O} \\
(\mathrm{ppm})\end{array}$ & $\begin{array}{c}\text { CEC } \\
(\mathrm{me} / 100 \mathrm{~g})\end{array}$ & $\begin{array}{c}\text { Base Saturation } \\
(\%)\end{array}$ & $\begin{array}{l}\text { Fertility } \\
\text { Class }\end{array}$ & $\begin{array}{l}\text { Limiting } \\
\text { Factor }\end{array}$ \\
\hline 1 & $S$ & Inceptisol & $7.7-7.0$ & $0.2-61.0-32.1$ & 1.23 & 2.32 & 0.20 & 0.0 & 12.0 & 156.1 & 22.81 & 100 & Low & $\begin{array}{c}\mathrm{CEC}, \\
\mathrm{P}_{2} \mathrm{O}_{5}, \mathrm{~K}_{2} \mathrm{O},\end{array}$ \\
\hline 2 & $P$ & Inceptisol & $5.0-4.1$ & $3.5-62.3-23.7$ & 1.09 & 1.84 & 0.19 & 0.47 & 2.5 & 116.4 & 13.24 & 58 & Low & CEC, $\mathrm{P}_{2} \mathrm{O}_{5}$, \\
\hline 3 & $P$ & Inceptisol & $5.1-4.4$ & $3.8-48.5-33.1$ & 0.98 & 3.47 & 0.39 & 0.19 & 1.6 & 146.7 & 22.64 & 50 & Low & $\mathrm{P}_{2} \mathrm{O}_{5}, \mathrm{~K}_{2} \mathrm{O}$, \\
\hline 4 & $s$ & Inceptisol & $7.3-7.3$ & $12.3-70.9-14.0$ & 1.32 & 1.51 & 0.10 & 0.0 & 32.0 & 87.1 & 9.16 & 100 & Low & $\mathrm{CEC}, \mathrm{K}_{2} \mathrm{O}, \mathrm{C}$ \\
\hline 5 & $P$ & Ultisol & $5.0-4.2$ & $1.4-56.0-30.1$ & 1.11 & 3.76 & 0.32 & 0.43 & 4.4 & 172.3 & 18.94 & 60 & Low & $\mathrm{P}_{2} \mathrm{O}_{5}, \mathrm{~K}_{2} \mathrm{O}$ \\
\hline 6 & $S F$ & Inceptisol & $4.7-3.9$ & $n a^{* *}$ & na & 31.32 & 1.67 & 1.39 & 30.4 & 221.4 & 53.88 & 21 & Low & $\begin{array}{c}\text { Base sat., } \\
\mathrm{K}_{2} \mathrm{O}\end{array}$ \\
\hline 7 & $P$ & Inceptisol & $4.8-4.0$ & $5.2-64.3-21.6$ & 1.00 & 2.84 & 0.26 & 0.56 & 8.9 & 116.8 & 16.86 & 57 & Low & $\begin{array}{c}\text { CEC, } \\
\mathrm{P}_{2} \mathrm{O}_{-} \mathrm{K}_{2} \mathrm{O}\end{array}$ \\
\hline 8 & G & Ultisol & $5.3-3.9$ & $0.4-62.8-25.6$ & 1.08 & 1.60 & 0.18 & 0.02 & 39.0 & 137.8 & 17.45 & 84 & Low & $\mathrm{K}_{2} \mathrm{O}$, C \\
\hline 9 & $S G$ & Inceptisol & $5.3-3.8$ & na & na & 3.82 & 0.31 & 0.23 & 15.4 & 104.6 & 22.77 & 67 & Low & $\mathrm{P}_{2} \mathrm{O}_{5}, \mathrm{~K}_{2} \mathrm{O}$ \\
\hline 10 & F & Inceptisol & $5.0-3.8$ & $2.3-54.6-27.7$ & 1.02 & 2.55 & 0.27 & 0.51 & 2.9 & 134.6 & 20.21 & 58 & Low & $\mathrm{P}_{2} \mathrm{O}_{5}, \mathrm{~K}_{2} \mathrm{O}$ \\
\hline 11 & $L$ & Inceptisol & $5.3-4.0$ & $0.0-38.4-49.4$ & 0.86 & 3.10 & 0.23 & 0.32 & 6.2 & 136.4 & 26.34 & 80 & Medium & $\mathrm{P}_{2} \mathrm{O}_{5}, \mathrm{~K}_{2} \mathrm{O}$ \\
\hline 12 & $L$ & Entisol & $5.5-4.7$ & $0.3-44.3-43.1$ & 0.78 & 2.81 & 0.24 & 0.18 & 34.0 & 149.8 & 27.05 & 86 & Medium & $\mathrm{K}_{2} \mathrm{O}$ \\
\hline 13 & F & Inceptisol & $5.4-4.0$ & $2.1-58.0-25.3$ & 1.11 & 2.12 & 0.28 & 0.19 & 10.7 & 90.2 & 18.33 & 66 & Low & $\mathrm{P}_{2} \mathrm{O}_{5}, \mathrm{~K}_{2} \mathrm{O}$ \\
\hline 14 & $F$ & Inceptisol & $5.7-4.5$ & $17.3-58.1-16.6$ & 1.27 & 0.86 & 0.12 & 0.04 & 19.0 & 65.1 & 11.10 & 86 & Low & $\begin{array}{r}\mathrm{CEC}, \mathrm{P}_{2} \mathrm{O}_{5}, \\
\mathrm{~K}_{2} \mathrm{O}, \mathrm{C}\end{array}$ \\
\hline 15 & $F$ & Ultisol & $5.2-3.9$ & $0.4-59.0-27.9$ & 1.23 & 1.64 & 0.22 & 0.88 & 8.8 & 97.3 & 16.82 & 60 & Low & $\mathrm{CEC}, \mathrm{P}_{2} \mathrm{O}_{5}$, \\
\hline 16 & $F$ & Inceptisol & $5.2-3.9$ & $0.3-57.0-28.8$ & 0.99 & 2.80 & 0.32 & 0.34 & 2.2 & 118.7 & 19.78 & 54 & Low & $\begin{array}{c}\mathrm{K}_{2} \mathrm{O}, \mathrm{C} \\
\mathrm{P}_{2} \mathrm{O}_{5}, \mathrm{~K}_{2} \mathrm{O}\end{array}$ \\
\hline 17 & $S G$ & Entisol & $5.1-4.0$ & na & na & 5.68 & 0.43 & 0.43 & 5.2 & 102.3 & 29.69 & 55 & Medium & $\mathrm{P}_{2} \mathrm{O}_{5}, \mathrm{~K}_{2} \mathrm{O}$ \\
\hline
\end{tabular}

*Vegetation types: $P=$ primary $S=$ swamp; $L=$ lakeside forest, $S F=$ sago forest; $F=$ fallow (secondary forest); $M G=$ mixed garden; $S G=$ sago garden. ${ }^{* *}$ Not applicable (dominated by organic matter).

\subsection{Local Knowledge of Soils and Land Use}

Local informants shared their knowledge of soils, land, and land-use practices through discussions and interviews. The main value of soil is for cultivation, but clay is also used in medicines, to build ovens, and to make children's toys. Informants said that, aside from seeking a convenient location, they evaluate land for cultivation mainly based on soil colour. Local nomenclature and evaluation of soils was simple: only four terms were used to describe soils in the 17 plots, and three referred to colour alone. In Khu, these terms are "Kigepo" (black), "Piake" (fertile), "Dite" (red), and "Kutawei" (meaning "white" but here used to describe pale grey soils). Note that these labels are not exclusive, as "Kigepo" are 
generally also noted to be "Piake". All informants agreed that the humus-rich "Kigepo", found on well-drained alluvial plains, are the most fertile and easiest to cultivate.

\section{Discussion}

\subsection{Land and Vegetation}

The sediment-rich rivers of the Mamberamo Basin support "white water" systems comparable to Amazonia's várzea forests [72,73]. As seen elsewhere, botanical diversity in flooded forests is lower than in neighbouring dryland $[74,75]$ but nonetheless includes numerous distinct and specialised taxa [72,76]. Disturbance is frequent as channels meander (Figure 2), flood depth and duration varies, and sediment deposition combined with variation in water chemistry and nutrient availability yields a wide range of challenging conditions that favour specialisation $[77,78]$.

Some plots had basal-area values that would be judged high in terrestrial forests-both swamp forests (plots 1 and 4) had values over $30 \mathrm{~m}^{2} \mathrm{ha}^{-1}$, and one lakeside plot (12) reached $45.1 \mathrm{~m}^{2} \mathrm{ha}^{-1}$. Even higher values (e.g., $60 \mathrm{~m}^{2} \mathrm{ha}^{-1}$ and above) have been observed in flooded forests in Amazonia [79]. One possible explanation for the high basal area we recorded is the positioning of our relatively small plots in locations that avoid deeper channels (tree stems thus being constrained to a smaller area than the canopy). It may also result from additional illumination, due to open edges and reflected light close to water.

The vegetation of the Mamberamo Basin has not been described previously. Given the sparsity of previous information from the study area, we cannot identify typical characteristics with certainty $[16,80]$. Nonetheless, our general observations seem consistent with accounts from the wider region [16,80,81]. For example, as seen elsewhere, herbs and shrubs are scarce or absent where prolonged flooding occurs and fleshy climbers, thin woody lianas, and climbing ferns are common [16]. While each individual taxon we report here is known elsewhere, the seasonally flooded lakeside forests dominated by $B$. racemosa and $N$. orientalis represent a striking forest type that has not been previously described to our knowledge [16]. Floodplain dynamics reduce the ability of forests to reach great age too, meaning that many trees are best viewed as pioneers. This may explain the relatively low forest stature, while emergents, such as Intsia bijuga, valued for local construction (Figure 4c), occurred locally in interior areas that appeared intermediate with dryland. Previous inter-regional summaries have noted that the flora of New Guinea seems especially rich in disturbance-adapted taxa [82,83]. We suspect that, as seen in many flooded forests, the combination of disturbance, flood characteristics, and sediment movements have generated a complex and dynamic habitat that requires deeper investigations if we are to better understand the key processes and their interactions in generating and sustaining diversity $[84,85]$. For example, disturbance-tolerant species may persist better in landscapes undergoing anthropogenic modifications than other, less-tolerant, taxa. In terms of botanical affinities, we see both Asian and Australia-Pacific elements. For example, the Flagellariaceae, Myrtaceae, Myristicaceae, and Sapindaceae are typical of the Australia-Pacific region, while the Dipterocarpaceae and Araceae represent a moretypical Asian element. Interestingly, it is the flora of swamps and flooded forests, and associated palynology, that are often best preserved in the fossil record. The preservation of pollen-rich sediments in forest wetlands is often more extensive and consistent than that of better-drained vegetation [13,86]. The common genera, such as Barringtonia and Nauclea, are typical of those observed in many paleoclimate assessments and other stratigraphic studies across the region $[11,13,87]$.

The abundance of unnamed and unmatched botanical records in this region is a challenge. While this sometimes results from inadequate material, it also reflects the paucity of reference materials despite our collections being compared with Indonesia's largest botanical collections. While we cannot be certain in specific cases, we are confident that some of our un-named taxa are undescribed species, while most are little known and seldom collected. More generally, we note that new species-including typical swamp 
taxa-continue to be described across the region $[88,89]$. Clearly, more botanical collections are needed.

Sago forests remain neglected in global studies [90] despite an estimated $50,000 \mathrm{~km}^{2}$ occurring across Papua alone [51] (lower estimates have also been reported [91], though the definitions and basis for these various numbers are unclear). Sago forests appear to be associated with permanently wet but shallow swamps. While sago palms often occur in mixed forest, they also dominate extensive areas and are considered native to New Guinea as this is where their greatest genetic diversity occurs [80,92]. In our study, sago forest had exceptionally carbon-rich soils (>30\%). Such high values are a recognised property of other tropical wetland forests [17]. Given the extent and importance of these forests, both in terms of local livelihood, culture, conservation value, and potential carbon storage, their history, properties, and maintenance warrant greater research attention.

New Guinea is tectonically young, and sediments and soils result from rapid weathering. Basalts and "ophiolite" geology underly the wider region [93], which weather to make the Mamberamo Basin a recognized source of nutrient-rich sediments that flow into the Pacific Ocean [94]. This, coupled with the dynamic and sediment-laden rivers around Papasena, led us to expect relatively productive soils. Nonetheless, these soils appear poor when judged by application of the standard criteria used by the Indonesian Department of Agriculture for "permanent agriculture without fertilizers" [71,95] and indicated few opportunities for cropping without artificial inputs in primary forest and swamps, while mixed gardens and old fallows appeared marginal for dryland rice, coconuts, coffee, cocoa, candlenut, rubber, and oil palm. The main limiting factors varied by crop and site (Table 6), but better sites for all crops except sago tended to be on the slightly higher and less-waterlogged sites. This assessment likely reflects a combination of factors. Firstly, the exposed geology in the local mountains, as described to us, is comprised of sedimentary rocks that may have gone through previous cycles of uplift, leaching, and weathering, resulting in few nutrients. Secondly, the Indonesian standards are designed to be suitable across a broad range of settings including substantial volcanic regions with highly productive soils_conditions absent in both Papasena and Papua more generally. In any case, as the crop-focused criteria underline, poor drainage and flooding limit opportunities for agriculture without extensive investment.

\subsection{People's Relationship with Land and Vegetation}

Compared to many forest communities [23], the people of Papasena appeared to have relatively easy access to wild and cultivated food during the period of our study. While wild products were clearly important, local people describe themselves as farmers. This emphasis likely reflects the ease of collecting wild products compared to the perceived effort required for cultivation. The limited soil nomenclature, along with discussions, also suggests that cultivation, at least as currently practiced, is relatively new in these communities. More detail on these cultural aspects is discussed elsewhere [22,24,25,40,47]. We found that people in Papasena generally use the best black soils to cultivate maize, banana, peanut, sweet potato, and cassava, while "swampy soils" are used to cultivate sago. The least-favourable land for cultivation is associated with swamps and the mountains (the latter are said to possess reddish soils). Informants noted that specific rules govern land-use at sacred places including locations used as burial grounds, salt springs, and at locations with valued resources such as timber trees close to the settlement.

One recent review of ethnobotanical publications from across New Guinea argued that despite its recognised biocultural significance [96], the entire region remains "underinvestigated" with only 217 of the region's 1100 ethnic groups having any mention in any of the 488 studies published over the previous 130 years [97]. Few of these studies have been systematic; most have focused on particular taxa or values (notably medicinal uses). Our data addressed an ethnic group (Khu) not previously studied and took a broad approach; we gathered summary information on useful species primarily to initiate a 
broader discussion with people regarding how much locations and biomes were valued and what the implications of these valuations were.

Our informants displayed a rich knowledge of the plants and locations we investigated. The resulting tally of species-uses provides, at best, a superficial summary of such knowledge. The plants provide a broad range of uses and associated values including a diversity of medicinal uses. Due to their distance from modern treatment, traditional medicine remains important, although a preference for modern medicines was clearly expressed. The proportion of useful and valued species was broadly similar to other cultures and sites in the wider region [57,59]. The number of "Ornamental/ritual" and "Boat construction" uses observed in our plots seemed sparse-it appears that neither ritual crafts nor boat building involved the apparent diversity of plant knowledge and uses seen with some communities in, for example, Kalimantan [57]. Our multiple cross-checks among informants, and across sites (for common species), ensured reasonable consistency for the information - we were not aware of any intended deceptions, as has sometimes been noted by researchers elsewhere $[98,99]$. Nonetheless, we underline that we always told people not to share information if they were uncomfortable to do so, and we accepted that the information shared may be incomplete [20]. Accepting such doubts is necessary in ethnobotanical studies [62] and was important in building trust with communities that have learned to be guarded with outsiders.

The traditional shelters with raised floors commonly used by people in the region are made of pole wood, with the trunks and leaves of palms for the floor and roofs. People use wooden spoons for cooking and wrap food in green leaves. They make baskets from leaves of palms and string bags from Gnetum gnemon bark. Local people have a broad knowledge of what plants attract and/or are eaten by animals, and they use such plants (especially fruiting trees) to inform their hunting. For example, the fruit of Canarium sp. and a tree locally called "iderig" (species not determined) are frequently sought by wild pigs (Sus scrofa) and cassowaries (C. unappendiculatus) for their fruits, while people reported that fruits of another tree "arug" (species not determined) attract cuscus (Phalanger sp.) and kangaroos. Knowing the location of these plants and their period of fruiting guides where and when to hunt.

Mixed gardens are usually located in a convenient site, typically an old fallow field, although other sites, including forests, may also be selected if not preserved for their values. Cultivation of mixed gardens is typically a family activity that not only provides food but also other important resources such as wood for construction, or for firewood, and medicinal plants. While we were only present in the village for a few weeks, we had the impression that plant-based foods were scarce. Aside from abundant sago, there were occasional bananas, sweet potato, and fruit, but cooked green vegetables were scarce and included occasional Gnetum leaves and young fern fronds.

Sago, the main starch crop, grows naturally in the floodplains of the region but is also planted widely in wet areas near settlements [50,51]. Despite appearing common, sago is a valued resource. Productive sago areas with good access to water are valued and under clear ownership. Sago is processed in situ with water to wash the starch out of the shredded trunk (Figure $4 \mathrm{~d}$ ). Sago is known to be a productive crop with a potential to produce 20 tons dry starch per ha per year [91]. Other parts of the palm are also useful: for example, the leaves, petioles, and rachises are also used for roofing, basketry, and various crafts. The extraction of sago starch involves scraping the stem and filtering the starch with water. The resulting product is generally served as a boiled porridge or cooked into a drier cake using an earth oven. This is sometimes mixed with fish, meat (occasionally crocodile), or cooked vegetables such as the oil-rich fruit of red pandanus (Pandanus conoideus Lam.). Informants noted that other wild palms such as Caryota rumphiana, locally abundant in the mountains, can also be used for starch but require considerably more effort to process.

Sago gardens are actively created, managed, and maintained, which raises questions about the origin and nature of sago forests more generally. The role and scale of human activities in generating sago forests is debated, but anthropogenic origins appear plausi- 
ble given how well the palm regenerates when mixed swamp forests are cleared $[16,80]$. The palms are known to grow best with a near continual flow of fresh water [81]. They can reproduce by suckers from older stems as well as by seed, though seeds are rare on intensively managed palms, which are generally harvested before reproduction with any flower buds typically being removed before maturation so as to preserve the plant's starch reserves. The region's sago plants vary in leaf form, bark thickness, starch colour and taste, and spine density, leading to some debate over taxonomic subdivisions and local races-a phenomenon recognised across the region and likely reflecting human selection [51]. Distinct varieties, differentiated by the presence or absence of thorns, are recognized across New Guinea. For example, both are used by the coastal Ormu people and have even been given different botanical names in the past, although most botanists now consider them one species [50]. Both spined and spineless forms were cultivated in Papasena, although the spineless form appeared to be preferred. In the neighbouring community of Kwerba, the spined form was planted to mark ownership boundaries [50]. In our sites, palms appeared spinier in more distant sago forest (e.g., plot 6) than in sago gardens where cultivated spineless forms predominated (spiny forms being absent in plot 9 and a minority in plot 17).

Our survey had a restricted scope; by focusing on the plains, we neglected the highlands and mountains. The community see their territory in broader terms and noted the values of mountain forest and associated Damar forests as important types within their territory (which we could not visit due to distance). While people appear well able to fulfil their livelihood needs in the floodplains close to the settlement, this does not imply a low value for more-distant sites. Despite the journey requiring several days, most men had visited the Damar forest on the lower slopes of the Foja Mountains for hunting and for collecting resin. They reported that they had sometimes climbed higher to see the mountains and reported a luxurious forest with plenty of wildlife-notably birds, kangaroo, and cuscus - that cannot be found in the lowlands. Nonetheless, it was clear that they have no desire to visit these mountains more regularly or to settle there. The relationship and value are best expressed in terms of cultural significance and obligations-especially for those who had ancestral lands that included these areas. They do not see the abundant resources in these mountains as available but as protected by long-standing rules that must be respected and enforced (breaches will result in bad consequences, supernatural or earthly). Indeed, the people were sensitive about the mountains and saw their protection as an important obligation. Similar taboos and concerns focused on other more-localised sites in the lowlands too; these included an area of hot springs, and selected locations on the river where it was bad luck to make any unnecessary noise. Such respect for natural locations offers a powerful basis for conservation planning with the communities $[22,23,26,100]$.

With such low population densities, anthropogenic impacts to date have generally been minor and localised, and the communities show an awareness of the need to manage these impacts, having experienced it directly in the case of past overhunting of crocodiles-for an indepth examination and discussion of three other villages in the region see, [25]. Nonetheless, extractive activities do cause damage. For example, in Papasena, the valued matoa fruit (Pometia sp.) is often accessed by felling the tree, and this species is also cut for wood. Growth in demand, either locally or through market opportunities, may encourage such activities.

\subsection{Recent Developments and the Future}

Recent changes and development initiatives bring opportunities and threats. Decentralisation has created new districts, hence new government offices bringing immigration to, and urban development in, nearby towns (Kasonaweja and Burmeso). Commercial timber extraction has expanded, while coal mining and new hydroelectric projects are repeatedly mentioned. The Mamberamo floodplain's long-term status as an "intact wilderness" is therefore unclear [18]. Even within the last year (2021), a proposal to develop a 
hydropower dam to boost regional development has been revived and then abandoned again (authors pers. comm. from local officials).

The region is changing rapidly. Since our study, the regional population has been growing. Official data for the 23,814 $\mathrm{km}^{2}$ Mamberamo Raya Regency, an area that includes Papasena and $54 \%$ of the Mamberamo-Foja Wildlife Reserve, showed a population of 18,365 in $2010,21,301$ in 2015 , and 36,483 by 2020 , indicating an $11 \%$ annual growth over the last five years (https:/ / www.bps.go.id/, accessed on 19 September 2021). While we lack recent data, the three settlements of Papasena have grown too, and one new settlement "Sowaki" was established within the territory in 2014, through internal movements-all four settlements have gained the formal status of "official village" (Desa). There are planned roads, such as the Trans-Papua and the Merauke Integrated Food and Energy Estate "MIFEE" Highways, that include plans to link Trimuris and Kasonaweja with a road through the Mamberamo-Foja Wildlife Reserve (north of Papasena, see maps in [6]). The Mamberamo-Foja Wildlife Reserve also lost six square kilometres through an official excision process between 2014 and 2016 (1767.5 to $1761.6 \mathrm{~km}^{2}$ [27]). There are recent discussions led by the district government and local communities (through the organisation "Dewan Adat Mamberamo Raya") to further review and revise the status of this area to both strengthen its protection and to develop a zoning system compatible with the presence and aspirations of the local people.

Economic and political contexts remain in flux. In the past, commercial initiatives (e.g., cocoa plantations and drying of crocodile meat) have largely come and gone due to problems of market access. In some cases, such as with crocodile skins, they have witnessed the consequences of overharvesting, and new rules and oversight have, after initial scepticism, been accepted [25]. While people value new opportunities, they remain wary and see their role not just in terms of personal gains but also about their wider responsibilities, including those to future generations. The political context offers local people opportunities to assert their control over their lands and resources. The constitutional right of communities to their customary lands and forests has been upheld by Indonesia's Constitutional Court [32]. Nonetheless, despite initial enthusiasm and ambitious targets for "returning forest," progress has been limited [101-103]. While government initiatives, including various programs labelled "community forestry" give the impression of returning control to local people, they can be viewed as a more-limited "manifestation of the state's interest in accommodating the interests and involvement of local communities in forest management" [33]. In our view, such initiatives fall short in addressing local aspirations and autonomy in that the government authority and oversight is maintained [103-106]. We favour the precedence of local control and believe this is more in line with the intention of the constitutional ruling. In this context, the "Manokwari Declaration" [39] remains a welcome development and describes much-needed commitments; much now depends on the nature of regional development and their ability to prioritise the role of local people and their heritage [6].

Our field work relied on local people. As we had seen in studies elsewhere, working closely with the local people provided many benefits including the identification of locally relevant forest and land-cover types, guided access, and explanations of histories, use, and implications $[23,26,58,107-109]$. Our survey boosted local pride in the rich natural heritage and biodiversity of the region. Local people were previously unaware of the many species that do not occur elsewhere, and this became a frequent subject of discussion (Figure 5). Such discussions often led to more-detailed exchanges among researchers and the community about conservation, threats to the environment, and the sustainable use of forest resources. These mutually informed interactions clarified views and raised many specific issues for planning and action. As we had hoped, the goodwill built in these processes led to further collaborations $[25,26,40,46]$ including the permission for subsequent expeditions to visit the Foja Mountains [24]. 


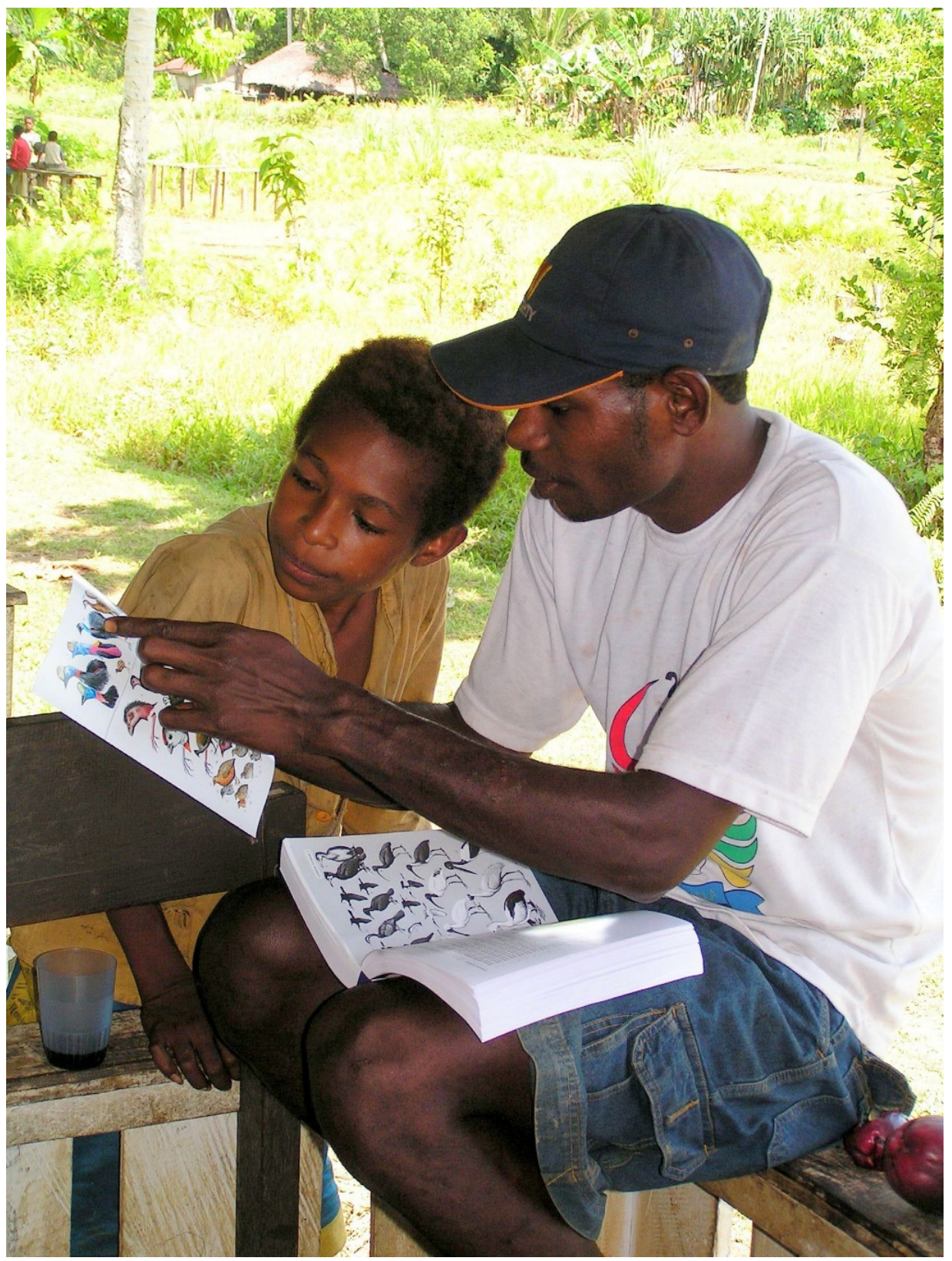

Figure 5. Collaboration stimulates curiosity and pride: here, local informant, Pak Parman, uses one of the research team's bird-identification books to explain to a child how the Northern Cassowaries, common in the nearby forests, are special to the region and do not occur elsewhere. Credit: D.S.

Conservation of this watershed and its biodiversity requires collaboration among local communities and official authorities [24]. Our approach assumed that this is the case and that conservation can, and should, be developed in collaboration with local people in a bottom-up fashion. It provided an initial shared understanding of issues and opportunities requiring further reflection and discussion. The justifications for such an approach are reviewed elsewhere [6,24,25,107,110-112]. Aside from the obvious ethical arguments, there are also pragmatic reasons: inclusive approaches to conservation developed with the guidance and support of local people are less likely to cause conflict and more likely to lead to effective conservation outcomes than non-inclusive approaches. Communities are more likely to benefit from and support approaches to both development and conservation where traditional institutions and decision-making are recognised as a primary form of oversight and decision making $[37,38]$. This remains relevant in Papasena, and Papua more 
generally, where conservation authorities remain largely absent and local customs and related institutions remain strong.

Our research in Mamberamo demonstrated to us that the local communities not only have considerable knowledge of their territories but have actively managed and protected these lands and rivers and their natural resources for centuries without external recognition or support [25]. The people are not merely open and sympathetic to conservation and sustainable management, they have been actively protecting these landscapes for generations, and their aspirations are that they will continue to do so in perpetuity. Recognizing the strength, value, and legitimacy of this local history and ownership offers often-neglected opportunities to build a collaborative strategy for protecting the Mamberamo Basin that respects and reflects local needs and values.

\section{Conclusions}

Our study provides a first look at a little-examined ecosystem of considerable importance. The value of Papua's floodplain areas has yet to gain the level of international recognition afforded to many other biodiversity hotspots, wilderness areas, and wetlands [6] The region is vulnerable to large-scale change as road building and other infrastructure projects open the area to development [6]. Attention is growing, locally and nationally, to ensure developments are carefully assessed, weighed, and planned in terms of their implications for people and nature [39]. Our results reflect our still-limited knowledge of Papua's floodplains and their ecology, and given proposed dam projects and other ongoing developments, there is a danger that these ecosystems, and their diverse local and global values, may be degraded and even destroyed before they have been formally recognised. Due to its biological importance, the protection of the Mamberamo Basin should be a priority. Local people have long protected these ecosystems and should be supported to do so into the future.

Author Contributions: D.S. led the project design and planning with support from all authors. All authors contributed to the field data collection, compilation, synthesis, and interpretation. I.R. led on botanical data site descriptions. I.B. led on soil data and analyses. Y.W. and M.B. led on community engagement and input. M.v.H. and M.W. led on data management. D.S. led the writing with detailed contributions from M.B. and M.v.H. All authors have read and agreed to the published version of the manuscript.

Funding: The training was supported by USAID and the Moore Foundation through Conservation International. More generally, CIFOR's work in developing these methods was supported by a grant from the International Tropical Timber Organization and later by the European Commission.

Institutional Review Board Statement: This research was not subjected to any institutional review. Please see methods section for a description of the legal and ethical standards.

Informed Consent Statement: Informed consent was obtained from all subjects involved in the study.

Data Availability Statement: Data are open access at https:/ / data.cifor.org/dataset.xhtml?persistentId= doi:10.17528/CIFOR/DATA.00277 (accessed on 5 December 2021).

Acknowledgments: We are grateful to the people of Papasena I for their patience, trust, and hospitality. We thank our team members and trainees who worked hard in difficult conditions and contributed to the data and results: Untung Ginting, BKSDA; Bambang Hariadi, UNIPA; Hendri Hariyadi, BKSDA; Hari Dwi Kristianto, ex-UNIPA; Jance Bemey, ex-UNCEN; Raffles Haruway, BAPEDALDA; Eddy Rudolf Charles Marien, ex-UNIPA; Dennis Piet Hein Koibur, ex-UNCEN. We also thank Scott Frazier, Tommy Wakum, Hugo Yoteni, Simon Petrus Inaury, Tommy, Fitri Ariyanti, Burhan Tjaturadi, Hendi Sumantri, Abdul Muthalib, Dessy Anggraeni, and Jim Peters (CI) and Pak Eko Baroto Waluja, head of the Bogor Herbarium, as well as Markku Kanninen, Ibu Rina (CIFOR), the Rector, Franz Wospakrik, and Johszua Mansoben, head of Lembaga Penelitian Universitas Cenderawasih (UNCEN) who hosted and supported our activities. Hubertus Matanubun, SU, head of Pusat Penelitian Lingkungan Hidup and his staff from the (UNIPA) also provided considerable support and assistance. We thank the BAPEDALDA and the BKSDA for their support and contribution, as well as the district authorities. We thank the Dewan Adat Mamberamo Raya (traditional council of 
Mamberamo) for its support of our activities. Two mission aviation services, AMA and TARIKU, brought us safely from Jayapura to the field and back. We thank the reviewers and editors for their careful reading and proposed improvements.

Conflicts of Interest: The authors declare no conflict of interest.

\section{References}

1. Cámara-Leret, R.; Frodin, D.G.; Adema, F.; Anderson, C.; Appelhans, M.S.; Argent, G.; Arias Guerrero, S.; Ashton, P.; Baker, W.J.; Barfod, A.S.; et al. New Guinea has the world's richest island flora. Nature 2020, 584, 579-583. [CrossRef]

2. Brooks, T.M.; Mittermeier, R.A.; Mittermeier, C.G.; Da Fonseca, G.A.; Rylands, A.B.; Konstant, W.R.; Flick, P.; Pilgrim, J.; Oldfield, S.; Magin, G. Habitat loss and extinction in the hotspots of biodiversity. Conserv. Biol. 2002, 16, 909-923. [CrossRef]

3. Myers, N.; Mittermeier, R.A.; Mittermeier, C.G.; Da Fonseca, G.A.; Kent, J. Biodiversity hotspots for conservation priorities. Nature 2000, 403, 853-858. [CrossRef]

4. Corlett, R.T.; Primack, R.B. Tropical Rain Forests: An Ecological and Biogeographical Comparison; John Wiley \& Sons: Oxford, UK, 2011.

5. Foley, W.A. The Languages of New Guinea. Annu. Rev. Anthropol. 2000, 29, 357-404. [CrossRef]

6. Gaveau, D.L.A.; Santos, L.; Locatelli, B.; Salim, M.A.; Husnayaen, H.; Meijaard, E.; Heatubun, C.; Sheil, D. Forest loss in Indonesian New Guinea (2001-2019): Trends, drivers and outlook. Biol. Conserv. 2021, 261, 109225. [CrossRef]

7. Beehler, B. Papuan terrestrial biogeography, with special reference to birds. In The Ecology of Papua; Marshall, A., Beehler, B., Eds.; Periplus: Singapore, 2007; pp. 196-206.

8. Supriatna, J.; De Fretes, Y.; Mack, A.; Yeager, C.; Olivieri, S.; Burnett, J.; Wijayanto, I.; Suryadi, S.; Suhandi, A. The Irian Jaya Biodiversity Conservation Priority-Setting Workshop (Final Report); Conservation International: Washington, DC, USA, 1999.

9. Van Heist, M.; Sheil, D.; Rachman, I.; Gusbager, P.; Raweyai, C.; Yoteni, H. The forests and related vegetation of Kwerba, on the Foja Foothills, Mamberamo, Papua (Indonesian New Guinea). Blumea-Biodivers. Evol. Biogeogr. Plants 2010, 55, $153-161$. [CrossRef]

10. Lohman, D.J.; de Bruyn, M.; Page, T.; von Rintelen, K.; Hall, R.; Ng, P.K.; Shih, H.-T.; Carvalho, G.R.; von Rintelen, T. Biogeography of the Indo-Australian archipelago. Annu. Rev. Ecol. Evol. Syst. 2011, 42, 205-226. [CrossRef]

11. Kooyman, R.M.; Morley, R.J.; Crayn, D.M.; Joyce, E.M.; Rossetto, M.; Slik, J.F.; Strijk, J.S.; Su, T.; Yap, J.-Y.S.; Wilf, P. Origins and assembly of Malesian rainforests. Annu. Rev. Ecol. Evol. Syst. 2019, 50, 119-143. [CrossRef]

12. Toussaint, E.F.; Hall, R.; Monaghan, M.T.; Sagata, K.; Ibalim, S.; Shaverdo, H.V.; Vogler, A.P.; Pons, J.; Balke, M. The towering orogeny of New Guinea as a trigger for arthropod megadiversity. Nat. Commun. 2014, 5, 4001. [CrossRef] [PubMed]

13. Morley, R.J. Origin and Evolution of Tropical Rain Forests; John Wiley \& Sons, Ltd.: Chichester, UK, 2000; p. 378.

14. Hall, R. Southeast Asia's changing palaeogeography. Blumea-Biodivers. Evol. Biogeogr. Plants 2009, 54, 148-161. [CrossRef]

15. Baldwin, S.L.; Fitzgerald, P.G.; Webb, L.E. Tectonics of the New Guinea region. Annu. Rev. Earth Planet. Sci. 2012, 40, 495-520. [CrossRef]

16. Johns, R.J.; Shea, G.A.; Puradyatmika, P. Lowland Swamp and Peat Vegetation of Papua. In The Ecology of Papua; Marshall, A.J., Beehler, B.M., Eds.; Periplus Editions: Singapore, 2007; pp. 910-944.

17. Murdiyarso, D.; Kauffman, J.B.; Verchot, L.V. Climate change mitigation strategies should include tropical wetlands. Carbon Manag. 2013, 4, 491-499. [CrossRef]

18. Sheil, D.; Cerutti, P.O.; Martius, C. Call of the wild: Define it or lose it. Nature 2021, 565, 429. [CrossRef]

19. Haarstad, J.; Sandbukt, Ø.; Deddy, K.; Disch, A. Environmental and Socio-Economic Baseline Study—Papua, Indonesia; Norwegian Agency for Development Cooperation: Oslo, Norway, 2009.

20. Sheil, D.; Puri, R.; Basuki, I.; van Heist, M.; Wan, M.; Liswanti, N.; Rukmiyati; Sardjono, M.A.; Samsoedin, I.; Sidiyasa, K.; et al. Exploring Biological Diversity, Environment and Local People's Perspectives in Forest Landscapes, 2nd ed.; CIFOR, MOF (Indonesia) and ITTO: Bogor, Indonesia, 2004.

21. Sheil, D.; Puri, R.; Wan, M.; Basuki, I.; van Heist, M.; Liswanti, N.; Rukmiyati; Rachmatika, I.; Samsoedin, I. Recognizing local people's priorities for tropical forest biodiversity. Ambio 2006, 35, 17-24. [CrossRef] [PubMed]

22. Boissière, M.; Liswanti, N.; Padmanaba, M.; Sheil, D. People Priorities and Perceptions. Towards Conservation Partnership in Mamberamo (Project Report); CIFOR: Bogor, Indonesia, 2007.

23. Boissiere, M.; Sassen, M.; Sheil, D.; Heist, M.; Jong, W.; Cunliffe, R.; Wan, M.; Padmanaba, M.; Liswanti, N.; Basuki, I. Researching local perspectives on biodiversity in tropical landscapes: Lessons from ten case studies. In Taking Stock of Nature: Participatory Biodiversity Assessment for Policy, Planning and Practice; Lawrence, A., Ed.; Cambridge University Press: Cambridge, UK, 2010; pp. 113-141.

24. Sheil, D.; Boissière, M. Local people may be the best allies in conservation. Nature 2006, 440, 868. [CrossRef] [PubMed]

25. Sheil, D.; Boissière, M.; Beaudoin, G. Unseen sentinels: Local monitoring and control in conservation's blind spots. Ecol. Soc. 2015, 20, 39. [CrossRef]

26. Van Heist, M.; Liswanti, N.; Boissière, M.; Padmanaba, M.; Basuki, I.; Sheil, D. Exploring Local Perspectives for Conservation Planning: A Case Study from a Remote Forest Community in Indonesian Papua. Forests 2015, 6, 3278-3303. [CrossRef]

27. Yoseph Watopa, S.; Ling, M.; Korwa, G.; Sos, S.; Lessil, N.; Kolop, D.N.; Rahmawan, F.; Piran, R.B.; Clara Caroline Bonai, S.; Ramandey, B.A. Mamberamo Foja Dari Suaka Margasatwa Menuju Taman Nasional; Deepublish: Yogyakarta, Indonesia, 2021.

28. Cyranoski, D. Calls to conserve biodiversity hotspots. Nature 2006, 439, 774. [CrossRef] [PubMed] 
29. Lynch, O.J.; Harwell, E. Whose Natural Resources? Whose Common Good. Towards a Paradigm of Environmental Justice and the National Interest in Indonesia; Centre for International Environment Law (CIEL): Washington, DC, USA; Jakarta, Indonesia, 2002; pp. 86, 190.

30. Wrangham, R. Changing Policy Discourses and Traditional Communities. In Which Way Forward?: People, FORESTS, and Policymaking in Indonesia; Colfer, C., Resosudarmo, d.A.P., Eds.; CIFOR: Bogor, Indonesia, 2002; pp. $20-35$.

31. Bedner, A.; Arizona, Y. Adat in Indonesian Land Law: A Promise for the Future or a Dead End? Asia Pac. J. Anthropol. 2019, 20, 416-434. [CrossRef]

32. Larson, A.M.; Monterroso, I.; Banjade, M.R.; Mwangi, E. Community rights to forests in the tropics: Progress and retreat on tenure reforms. In Comparative Property Law: Global Perspectives; Edward Elgar Publishing: Cheltenham, UK, 2016.

33. Ungirwalu, A.; Awang, S.A.; Runtuboi, Y.Y.; Peday, M.Y.; Marwa, J.; Maitar, B.; Murdjoko, A.; Fatem, S.M. Customary Forests in West Papua: Contestation of Desires or Needs? For. Soc. 2021, 5, 365-375. [CrossRef]

34. Margono, B.A.; Potapov, P.V.; Turubanova, S.; Stolle, F.; Hansen, M.C. Primary forest cover loss in Indonesia over 2000-2012. Nat. Clim. Chang. 2014, 4, 730-735. [CrossRef]

35. Gokkon, B. Indonesia's big development push in Papua: Q\&A with program overseer Judith J. Dipodiputro. Mongabay News, 27 October 2017.

36. Sloan, S.; Campbell, M.J.; Alamgir, M.; Engert, J.; Ishida, F.Y.; Senn, N.; Huther, J.; Laurance, W.F. Hidden challenges for conservation and development along the Trans-Papuan economic corridor. Environ. Sci. Policy 2019, 92, 98-106. [CrossRef]

37. Indrawan, M.; Sumule, A.; Wijaya, A.; Kapisa, N.; Wanggai, F.; Ahmad, M.; Mambai, B.V.; Heatubun, C.D. A time for locally driven development in Papua and West Papua. Dev. Pract. 2019, 29, 817-823. [CrossRef]

38. Karim, D.B. Whose development? The need for conflict-sensitive development in Papua, Indonesia. J. Peacebuild. Dev. 2012, 7, 95-100. [CrossRef]

39. Cámara-Leret, R.; Schuiteman, A.; Utteridge, T.; Bramley, G.; Deverell, R.; Fisher, L.A.; McLeod, J.; Hannah, L.; Roehrdanz, P.; Laman, T.G.; et al. The Manokwari Declaration: Challenges ahead in conserving 70\% of Tanah Papua's forests. For. Soc. 2019, 3, 148-151. [CrossRef]

40. Padmanaba, M.; Boissière, M.; Ermayanti; Sumantri, H.; Achdiawan, R. Perspectives on Collaborative Land Use Planning in Mamberamo Raya Regency, Papua, Indonesia: Case Studies from Burmeso, Kwerba, Metaweja, Papasena, and Yoke; CIFOR: Bogor, Indonesia, 2012.

41. Sadili, A.; Kartawinata, K.; Soedjito, H.; Edy, N.S. Tree species diversity in a pristine montane forest previously untouched by human activities in Foja Mountains, Papua, Indonesia. Reinwardtia 2018, 17, 133-154. [CrossRef]

42. Takeuchi, W. A floristic reconnaissance of montane environments in the Foja Mts. of Papua Province, Indonesia. Harv. Pap. Bot. 2010, 15, 11-25. [CrossRef]

43. Beehler, B.M.; Prawiradilaga, D.M.; de Fretes, Y.; Kemp, N. A new species of smoky honeyeater (Meliphagidae: Melipotes) from western New Guinea. Auk 2007, 124, 1000-1009. [CrossRef]

44. Boissière, M.; Herold, M.; Atmadja, S.; Sheil, D. The feasibility of local participation in Measuring, Reporting and Verification (PMRV) for REDD+. PLoS ONE 2017, 12, e0176897. [CrossRef]

45. Yoseph Watopa, S.; Ling, M. Valuasi Ekonomi Hutan Adat Papasena Dan Implikasinya Bagi Pengelolaan Suaka Margasatwa Mamberamo Foja; Deepublish: Yogyakarta, Indonesia, 2021.

46. Boissière, M.; Locatelli, B.; Sheil, D.; Padmanaba, M.; Sadjudin, E. Local Perceptions of Climate Variability and Change in Tropical Forests of Papua, Indonesia. Ecol. Soc. 2013, 18, 13. [CrossRef]

47. Boissière, M.; van Heist, M.; Sheil, D.; Basuki, I.; Frazier, S.; Ginting, U.; Wan, M.; Hariadi, B.; Hariyadi, H.; Kristianto, H.D. Pentingnya Sumberdaya Alam bagi Masyarakat Lokal di Daerah Aliran Sungai Mamberamo, Papua, dan Implikasinya bagi Konservasi (in Indonesian). J. Trop. Ethnobiol. 2004, 1, 76-95.

48. Nilsson, C.; Reidy, C.A.; Dynesius, M.; Revenga, C. Fragmentation and flow regulation of the world's large river systems. Science 2005, 308, 405-408. [CrossRef]

49. Murdiyarso, D.; Kurnianto, S. Ecohydrology of the Mamberamo Basin: An Initial Assessment of Biophysical Processes; Center for International Forestry Research: Bogor, Indonesia, 2008.

50. Boissiere, M.; Purwanto, Y. The agricultural systems of Papua. In Ecology of Papua; Marshall, A., Beehler, B., Eds.; Periplus: Singapore, 2007; pp. 1125-1158.

51. Schuiling, D.L.; Jong, F.S. Metroxylon sagu Rottboell. Plant resources of South-East Asia (PROSEA) N 9 , Plants Yielding Non-Seed Carbohydrates 1996, 9, 121-126.

52. Salo, J.; Kalliola, R.; Hakkinen, I.; Makinen, Y.; Niemela, P.; Puhakka, M.; Coley, P.D. River dynamics and the diversity of Amazon lowland forest. Nature 1986, 322, 254-258. [CrossRef]

53. Marshall, A.J.; Beehler, B.M. (Eds.) The Ecology of Papua; Periplus Editions: Singapore, 2007; pp. 749, 768.

54. Jayan, T. 40 New Species. Available online: https:/ /www.downtoearth.org.in/coverage/40-new-species-7526 (accessed on 9 December 2021).

55. Anon. New Species Found in "Lost World". Available online: https://www.nationalgeographic.com/science/article/100517 -new-species-lost-world-foja-science-pictures (accessed on 9 December 2021).

56. Choi, C. Finding a Lost World. Sci. Am. 2006, 294, 32. [CrossRef] 
57. Sheil, D.; van Heist, M.; Liswanti, N.; Basuki, I.; Wan, M. Biodiversity and landscapes: A local perspective. In The Decentralization of Forest Governance: Politics, Economics and the Fight for Control of Forest in Indonesian Borneo; Moelino, M., Wollenberg, E., Limberg, G., Eds.; Earthscan: London, UK, 2008; pp. 61-90.

58. Basuki, I.; Sheil, D. Local Perspectives of Forest Landscapes: A Preliminary Evaluation of Land and Soils, and their Importance in Malinau, East Kalimantan, Indonesia; CIFOR: Bogor, Indonesia, 2005.

59. Sheil, D.; Salim, A. Diversity of locally useful tropical forest wild-plants as a function of species richness and informant culture. Biodivers. Conserv. 2012, 21, 687-699. [CrossRef]

60. Liswanti, N.; Sheil, D.; Basuki, I.; Padmanaba, M.; Mulcahy, G. Falling back on forests: How forest-dwelling people cope with catastrophe in a changing landscape. Int. For. Rev. 2011, 13, 442-455. [CrossRef]

61. Padmanaba, M.; Sheil, D.; Basuki, I.; Liswanti, N. Accessing local knowledge to identify where species of conservation concern occur in a tropical forest landscape. Environ. Manag. 2013, 52, 348-359. [CrossRef]

62. Cunningham, A.B. Professional ethics and ethnobotanical research. Adv. Econ. Bot. 1996, 10, 19-51.

63. Gamborg, C.; Parsons, R.; Puri, R.K.; Sandøe, P. Ethics and research methodologies for the study of traditional forest-related knowledge. In Traditional Forest-Related Knowledge; Parrotta, J.A., Trosper, R.L., Eds.; Springer: Dordrecht, The Netherlands, 2012; pp. 535-562.

64. Sheil, D.; Ducey, M.J.; Sidiyasa, K.; Samsoedin, I. A new type of sample unit for the efficient assessment of diverse tree communities in complex forest landscapes. J. Trop. For. Sci. 2003, 15, 117-135.

65. Nath, C.D.; Pélissier, R.; Garcia, C. Comparative efficiency and accuracy of variable area transects versus square plots for sampling tree diversity and density. Agrofor. Syst. 2010, 79, 223-236. [CrossRef]

66. Kershaw, J.A., Jr.; Ducey, M.J.; Beers, T.W.; Husch, B. Forest Mensuration; John Wiley \& Sons: Oxford, UK, 2016.

67. Gillison, A.; Carpenter, G. A generic plant functional attribute set and grammar for dynamic vegetation description and analysis. Funct. Ecol. 1997, 11, 775-783. [CrossRef]

68. Sheil, D.; Sayer, J.A.; O'Brien, T. Tree diversity and conservation in logged rainforest. Science 1999, 284, 1587. [CrossRef]

69. Suwardi, H.; Wiranegara. Penuntun Praktikum Klasifikasi dan Morfologi Tanah; Institut Pertanian: Bogor, Indonesia, 1998. (In Indonesian)

70. Eviati; Sulaeman, M. Analisis Kimia Tanah, Tanaman, Air, dan Pupuk, Petunjuk Teknis, Edisi 2 (Analyses of Soil Chemical, Plant, Water, and Fertiliser, Technical Guide, Second Edition); Balai Penelitian Tanah: Bogor, Indonesia, 2009; Volume 246, p. 234.

71. Bina-Program. Kriteria Evaluasi Kesesuaian Lahan; Departemen Pertanian, Indonesia: Bogor, Indonesia, 1997.

72. Ghazoul, J.; Sheil, D. Tropical Rain Forests Ecology, Diversity and Conservation; Oxford University Press: Oxford, UK, 2010.

73. Wittmann, F.; Junk, W.J.; Piedade, M.T.F. The varzea forests in Amazonia: Flooding and the highly dynamic geomorphology interact with natural forest succession. For. Ecol. Manag. 2004, 196, 199-212. [CrossRef]

74. Assis, R.L.; Haugaasen, T.; Schöngart, J.; Montero, J.C.; Piedade, M.T.; Wittmann, F. Patterns of tree diversity and composition in Amazonian floodplain paleo-várzea forest. J. Veg. Sci. 2015, 26, 312-322. [CrossRef]

75. Stevenson, P.R.; Aldana, A.M.; Cárdenas, S.; Negret, P.J. Flooding and soil composition determine beta diversity of lowland forests in Northern South America. Biotropica 2018, 50, 568-577. [CrossRef]

76. Bredin, Y.K.; Hawes, J.E.; Peres, C.A.; Haugaasen, T. Structure and Composition of Terra Firme and Seasonally Flooded Várzea Forests in the Western Brazilian Amazon. Forests 2020, 11, 1361. [CrossRef]

77. Mori, G.B.; Schietti, J.; Poorter, L.; Piedade, M.T.F. Trait divergence and habitat specialization in tropical floodplain forests trees. PLoS ONE 2019, 14, e0212232. [CrossRef]

78. Parolin, P.; De Simone, O.; Haase, K.; Waldhoff, D.; Rottenberger, S.; Kuhn, U.; Kesselmeier, J.; Kleiss, B.; Schmidt, W.; Piedade, M.T.F.; et al. Central Amazonian floodplain forests: Tree adaptations in a pulsing system. Bot. Rev. 2004, 70, 357-380. [CrossRef]

79. Klinge, H.; Adis, J.; Worbes, M. The vegetation of a seasonal várzea forest in the lower Solimões river, Brazilian Amazonia. Acta Amaz. 1995, 25, 201-220. [CrossRef]

80. Paijmans, K. (Ed.) New Guinea Vegetation; CSIRO in association with Australian National University: Canberra, Australia, 1976.

81. Osborne, P.L. Wetlands of Papua New Guinea. In Wetlands of the world: Inventory, Ecology and Management Volume I: Africa, Australia, Canada and Greenland, Mediterranean, Mexico, Papua New Guinea, South Asia, Tropical South America, United States; Whigham, D.F., Dykyjová, D., Hejný, S., Eds.; Springer: Dordrecht, The Netherlands, 1993; pp. 305-344.

82. Johns, R.J. The instability of the tropical ecosystem in New-Guinea. Blumea 1986, 31, 341-371.

83. Whitmore, T.C. An Introduction to Tropical Rain Forests, 2nd ed.; Oxford University Press: Cambridge, UK, 1998; pp. 282, xiii.

84. Whitmore, T.; Burslem, D. Major disturbances in tropical rainforests. In Dynamics of Tropical Communities; Newbery, D., Prins, H., Brown, N., Eds.; Cambridge University Press: Cambridge, UK, 1998; pp. 549-565.

85. Sheil, D.; Burslem, D. Disturbing hypotheses in tropical forests. Trends Ecol. Evol. 2003, 18, 18-26. [CrossRef]

86. Van Gorsel, J.; Lunt, P.; Morley, R.J.B.S. Introduction to Cenozoic biostratigraphy of Indonesia-SE Asia. Ber. Sedimentol. 2014, 29, 6-40.

87. Horton, B.P.; Gibbard, P.L.; Milne, G.M.; Morley, R.J.; Purintavaragul, C.; Stargardt, J.M. Holocene sea levels and palaeoenvironments, Malay-Thai Peninsula, southeast Asia. Holocene 2005, 15, 1199-1213. [CrossRef]

88. Jebb, M.; Prance, G. Five new species of Barringtonia (Lecythidaceae) from Papua New Guinea. Blumea 2011, 56, 105-112. [CrossRef] 
89. Takeuchi, W. New taxa from the Mamberamo River of Papua Province, Indonesia: Ardisia lammersiana (Myrsinaceae) and Psychotria leptothyrsa var. defretesiana (Rubiaceae). Harv. Pap. Bot. 2009, 14, 173-181. [CrossRef]

90. Muscarella, R.; Emilio, T.; Phillips, O.L.; Lewis, S.L.; Slik, F.; Baker, W.J.; Couvreur, T.L.P.; Eiserhardt, W.L.; Svenning, J.-C.; Affum-Baffoe, K.; et al. The global abundance of tree palms. Glob. Ecol. Biogeogr. 2020, 29, 1495-1514. [CrossRef]

91. Sidiq, F.F.; Coles, D.; Hubbard, C.; Clark, B.; Frewer, L. Sago and the indigenous peoples of Papua, Indonesia: A review. J. Agric. Appl. Biol. 2021, 2, 138-149. [CrossRef]

92. Kjaer, A.; Barfod, A.S.; Asmussen, C.B.; Seberg, O. Investigation of genetic and morphological variation in the sago palm (Metroxylon sagu; Arecaceae) in Papua New Guinea. Ann. Bot. 2004, 94, 109-117. [CrossRef]

93. Monnier, C.; Girardeau, J.; Pubellier, M.; Permana, H. L'ophiolite de la chaîne centrale d'Irian Jaya (Indonésie): Evidences pétrologiques et géochimiques pour une origine dans un bassin arrière-arc. Comptes Rendus Académie Sci.-Ser. IIA-Earth Planet. Sci. 2000, 331, 691-699. [CrossRef]

94. Muchtar, M. IndoTROPICS studies on the plume of the Mamberamo river into the Bismarck Sea, West Papua, Indonesia. Cont. Shelf Res. 2004, 24, 2521-2533. [CrossRef]

95. Subagjo, H.; Suharta, N.; Siswanto, A. Tanah-tanah pertanian di Indonesia. In Sumberdaya Lahan Indonesia dan Pengelolaannya; Adimihardja, A., Li, A., Djaenudin, D., Eds.; Pusat Penelitian dan Pengembangan Tanah dan Agroklimat/Center for Soil and Agroclimate Research and Development: Bogor, Indonesia, 2004; pp. 21-66.

96. Gorenflo, L.J.; Romaine, S.; Mittermeier, R.A.; Walker-Painemilla, K. Co-occurrence of linguistic and biological diversity in biodiversity hotspots and high biodiversity wilderness areas. Proc. Natl. Acad. Sci. USA 2012, 109, 8032-8037. [CrossRef] [PubMed]

97. Cámara-Leret, R.; Dennehy, Z. Indigenous knowledge of New Guinea's useful plants: A review. Econ. Bot. 2019, 73, 405-415. [CrossRef]

98. Nachman, S.R. Lies my informants told me. J. Anthropol. Res. 1984, 40, 536-555. [CrossRef]

99. Long, N.; Bruner, E.M.; Mookherjee, N. Discussion point: When informants lie. Camb. J. Anthropol. 2009, 29, 85-94.

100. Colding, J.; Folke, C. Social taboos: "Invisible" systems of local resource management and biological conservation. Ecol. Appl. 2001, 11, 584-600.

101. Ragandhi, A.; Hadna, A.H.; Setiadi, S.; Maryudi, A. Why do greater forest tenure rights not enthuse local communities? An early observation on the new community forestry scheme in state forests in Indonesia. For. Soc. 2021, 5, 159-166. [CrossRef]

102. Maryudi, A.; Sahide, M.A.K.; Daulay, M.H.; Yuniati, D.; Syafitri, W.; Sadiyo, S.; Fisher, M.R. Holding social forestry hostage in Indonesia: Contested bureaucracy mandates and potential escape pathways. Environ. Sci. Policy 2022, 128, 142-153. [CrossRef]

103. De Royer, S.; Van Noordwijk, M.; Roshetko, J. Does community-based forest management in Indonesia devolve social justice or social costs? Int. For. Rev. 2018, 20, 167-180. [CrossRef]

104. Myers, R.; Intarini, D.; Sirait, M.T.; Maryudi, A. Claiming the forest: Inclusions and exclusions under Indonesia's 'new' forest policies on customary forests. Land Use Policy 2017, 66, 205-213. [CrossRef]

105. Fatem, S.M. Connecting social forestry to conservation policies in Tanah Papua. For. Soc. 2019, 3, 141-147. [CrossRef]

106. Budi, B.; Kartodihardjo, H.; Nugroho, B.; Mardiana, R. Implementation of social forestry policy: A review of community access. For. Soc. 2021, 5, 60-74. [CrossRef]

107. Sheil, D.; Lawrence, A. Tropical biologists, local people and conservation: New opportunities for collaboration. Trends Ecol. Evol. 2004, 19, 634-638. [CrossRef] [PubMed]

108. Sassen, M.; Jum, C. Assessing local perspectives in a forested landscape of central Cameroon. For. Trees Livelihoods 2007, 17, $23-42$. [CrossRef]

109. Sassen, M.; Wan, M. Biodiversity and local priorities in a community near the Ivindo National Park Makokou, Gabon; CIFOR: Bogor, Indonesia, 2006.

110. Kaimowitz, D.; Sheil, D. Conserving what and for whom? Why conservation should help meet basic human needs in the tropics. Biotropica 2007, 39, 567-574. [CrossRef]

111. Lynam, T.; de Jong, W.; Sheil, D.; Kusumanto, T.; Evans, K. A review of tools for incorporating community knowledge, preferences, and values into decision making in natural resources management. Ecol. Soc. 2007, 12, 5. [CrossRef]

112. Sayer, J.; Sunderland, T.; Ghazoul, J.; Pfund, J.L.; Sheil, D.; Meijaard, E.; Venter, M.; Boedhihartono, A.K.; Day, M.; Garcia, C.; et al. Ten principles for a landscape approach to reconciling agriculture, conservation, and other competing land uses. Proc. Natl. Acad. Sci. USA 2013, 110, 8349-8356. [CrossRef] 